\title{
Land cover change impacts on atmospheric chemistry: simulating projected large-scale tree mortality in the United States
}

\author{
Jeffrey A. Geddes ${ }^{1}$, Colette L. Heald ${ }^{2}$, Sam J. Silva ${ }^{2}$, and Randall V. Martin ${ }^{1,3}$ \\ ${ }^{1}$ Department of Physics and Atmospheric Science, Dalhousie University, P.O. Box 15000, Halifax, \\ Nova Scotia, B3H 4R2, Canada \\ ${ }^{2}$ Department of Civil and Environmental Engineering, Massachusetts Institute of Technology, \\ 77 Massachusetts Avenue, Cambridge, Massachusetts 02139-4307, USA \\ ${ }^{3}$ Harvard-Smithsonian Center for Astrophysics, Cambridge, Massachusetts, USA \\ Correspondence to: Jeffrey A. Geddes (jeff.geddes@dal.ca)
}

Received: 28 September 2015 - Published in Atmos. Chem. Phys. Discuss.: 28 October 2015

Revised: 1 February 2016 - Accepted: 8 February 2016 - Published: 29 February 2016

\begin{abstract}
Land use and land cover changes impact climate and air quality by altering the exchange of trace gases between the Earth's surface and atmosphere. Large-scale tree mortality that is projected to occur across the United States as a result of insect and disease may therefore have unexplored consequences for tropospheric chemistry. We develop a land use module for the GEOS-Chem global chemical transport model to facilitate simulations involving changes to the land surface, and to improve consistency across land-atmosphere exchange processes. The model is used to test the impact of projected national-scale tree mortality risk through 2027 estimated by the 2012 USDA Forest Service National Insect and Disease Risk Assessment. Changes in biogenic emissions alone decrease monthly mean $\mathrm{O}_{3}$ by up to $0.4 \mathrm{ppb}$, but reductions in deposition velocity compensate or exceed the effects of emissions yielding a net increase in $\mathrm{O}_{3}$ of more than $1 \mathrm{ppb}$ in some areas. The $\mathrm{O}_{3}$ response to the projected change in emissions is affected by the ratio of baseline $\mathrm{NO}_{x}$ : $\mathrm{VOC}$ concentrations, suggesting that in addition to the degree of land cover change, tree mortality impacts depend on whether a region is $\mathrm{NO}_{x}$-limited or $\mathrm{NO}_{x}$-saturated. Consequently, air quality (as diagnosed by the number of days that $8 \mathrm{~h}$ average $\mathrm{O}_{3}$ exceeds $70 \mathrm{ppb}$ ) improves in polluted environments where changes in emissions are more important than changes to dry deposition, but worsens in clean environments where changes to dry deposition are the more important term. The influence of changes in dry deposition demonstrated here underscores the need to evaluate treatments of this physical process in models. Biogenic secondary organic aerosol loadings
\end{abstract}

are significantly affected across the US, decreasing by $5-$ $10 \%$ across many regions, and by more than $25 \%$ locally. Tree mortality could therefore impact background aerosol loadings by between 0.5 and $2 \mu \mathrm{g} \mathrm{m}^{-3}$. Changes to reactive nitrogen oxide abundance and partitioning are also locally important. The regional effects simulated here are similar in magnitude to other scenarios that consider future biofuel cropping or natural succession, further demonstrating that biosphere-atmosphere exchange should be considered when predicting future air quality and climate. We point to important uncertainties and further development that should be addressed for a more robust understanding of land cover change feedbacks.

\section{Introduction}

Land use and land cover changes impact climate by altering energy exchange at the surface of the Earth, and by altering the composition of the atmosphere through changes in biogeochemical cycling (Feddema et al., 2005; Pielke et al., 2011). Though recognized as a crucial factor in future climate scenarios (van Vuuren et al., 2011), projections of land use and land cover change remain highly uncertain (Smith et al., 2010). The terrestrial biosphere also plays an important role in surface-atmosphere exchange of reactive trace species that control the oxidative chemistry of the troposphere (Arneth et al., 2010; Laothawornkitkul et al., 2009; Mellouki et al., 2015; Monson and Holland, 2001), so that 
changes in vegetation can further impact air quality and climate (Heald and Spracklen, 2015; Unger, 2014). These changes can be human-driven (e.g., urbanization, forestry management, and agricultural practices) or natural (e.g., wildfires, insect infestations, and biome shifts). Over the 21 st century, variations in biogenic volatile organic compound (BVOC) emissions due to climate change and crop management will likely impact surface ozone $\left(\mathrm{O}_{3}\right)$ and secondary organic aerosol (SOA) concentrations (Ashworth et al., 2012; Chen et al., 2009; Ganzeveld et al., 2010; Hardacre et al., 2013; Heald et al., 2008; Wu et al., 2012). Here we consider the air quality and atmospheric chemistry implications of another form of land cover change on relatively shorter timescales: large-scale insect- and disease-driven tree mortality.

Modifications to vegetation distribution, plant type, canopy characteristics, and soil properties alter the regional emission and deposition of reactive trace gases from the terrestrial biosphere. For example, large-scale deforestation of the Amazonian rainforest, the expansion of oil palm plantations in Asia, and cultivation of biofuel feedstocks can significantly alter BVOC emissions, with various implications for secondary pollutants (Ashworth et al., 2012; Beltman et al., 2013; Ganzeveld, 2004; MacKenzie et al., 2011). In the eastern US, harvest practices and forest management have likely resulted in a net increase in BVOC emissions since the 1980s, counteracting successful anthropogenic emission reductions (Purves et al., 2004). Ecological succession, either from anthropogenic land management or natural processes, could also impact regional chemistry (Drewniak et al., 2014). Some changes in land cover have compensating impacts. For example, higher vegetation density could lead to increased $\mathrm{O}_{3}$ precursor emissions but also faster depositional losses (Ganzeveld et al., 2010; Wu et al., 2012). Consequently, we require models that account for the combination of these mechanisms in a consistent manner to understand the relevant net impacts on air quality and climate.

Almost a third of the Earth's land surface is covered by forests, providing a variety of economic, recreational, and ecosystem services including regulating climate through complex biogeophysical and hydrological feedbacks and by taking up $\mathrm{CO}_{2}$ from the atmosphere (Bonan, 2008; MEA, 2005). A prominent risk to forests in the near future ( $<$ decades) is tree mortality resulting from insect attack and disease (Krist et al., 2014). Biotic disturbances resulting in tree mortality occur naturally at low and predictable rates (Smith et al., 2001), but in the coming decades many forests across the US are predicted to experience tree mortality well above background. Between 2013 and 2027, over 80 million acres of treed land in the United States are projected to experience basal area mortality rates exceeding $25 \%$, with some tree species at risk of losing more than $50 \%$ of their volume (Krist et al., 2014). The dominant contributing hazards are expected to be root diseases, bark beetles, and oak decline, with highest risks occurring in Idaho, Montana, and
Oregon in the western US and in Rhode Island, Connecticut, and Massachusetts in the eastern US (Krist et al., 2014). The wood volume lost from insects and pathogens can cost the US several times more than losses by wildfire (Dale et al., 2001), and can have a major impact on carbon cycling (Hicke et al., 2012), but the atmospheric chemistry impacts have not been fully explored. Berg et al. (2013) simulated the impact of past bark beetle infestations in the western US using a decade of tree mortality data. They found large changes to monoterpene emissions, and subsequently SOA concentrations, that could potentially affect background aerosol concentrations and visibility in pristine regions.

Given the important role of natural emissions in the chemistry of the atmosphere (Zare et al., 2014), large-scale future tree mortality may influence ozone production and organic aerosol concentrations. Nonattainment of $\mathrm{O}_{3}$ air quality standards in the US is more sensitive to BVOC emissions than anthropogenic VOC emissions (Hakami et al., 2006), and secondary organic aerosol mass can be dominated by biogenic sources (Pye et al., 2010). The main anticipated effect of tree mortality is a reduction of the BVOC emissions from the species that die, but a change in local vegetation density would also be expected to impact dry deposition, since this is directly related to the surface area available for deposition. Vegetation changes can also affect the local microclimate, further impacting depositional processes. Changes in dry deposition may be significant for species (such as $\mathrm{O}_{3}$ ) whose depositional losses are competitive with chemical sinks near the surface of the earth. Finally, since soil $\mathrm{NO}_{x}$ emissions to the atmosphere depend not only on available nitrogen and soil conditions but also on the extent of uptake to vegetation canopies, changes to forests driven by tree mortality could impact these emissions as well.

Here we use the GEOS-Chem chemical transport model to investigate the impact of projected tree mortality on atmospheric composition. We harmonize the description of land cover across the relevant surface-atmosphere exchange processes, and use this adapted model to simulate the impacts of predicted tree losses as a result of insect and disease in the United States from 2013-2027. We explore how changes in dry deposition might compensate for changes in chemical production by separating these impacts in individual simulations. We highlight that even modest tree mortality could impact regional atmospheric chemistry across the US, and identify specific regions for further investigation. We also discuss directions for future development to better understand the influence of vegetation changes on atmospheric reactivity and composition. 


\section{Model description}

\subsection{General description of GEOS-Chem}

We use the GEOS-Chem model (Bey et al., 2001; www. geos-chem.org) v9-02 to simulate the impact of changes in vegetation on atmospheric chemistry. GEOS-Chem is a global 3-D atmospheric chemical transport model driven by assimilated meteorology from the NASA Global Modeling and Assimilation Office. Our simulations are driven by GEOS-5 meteorological data for the year 2010 and performed over North America at the nested horizontal resolution of $0.5^{\circ} \times 0.667^{\circ}$, with dynamic boundary conditions supplied from a global simulation at $2^{\circ} \times 2.5^{\circ}$.

The model includes a detailed $\mathrm{HO}_{x}-\mathrm{NO}_{x}-\mathrm{VOC}-\mathrm{O}_{3}$ chemical scheme originally presented by Bey et al. (2001). The chemical mechanism includes over 90 species (including the following lumped categories: > C3 alkanes, >C2 alkenes, $>\mathrm{C} 4$ alkynitrates, > 1 aldehydes, $>\mathrm{C} 1$ alcohols, and $>\mathrm{C} 1$ organic acids), over 200 chemical reactions, and over 50 photolysis reactions, incorporating the latest JPL and IUPAC recommendations. Detailed isoprene oxidation chemistry is included, following Paulot et al. (2009a, b) as implemented for GEOS-Chem by Mao et al. (2013). Explicit oxidation pathways are not yet included for terpenes. Given that isoprene dominates biogenic $\mathrm{OH}$ reactivity over the continental US, we assume terpenes play a minor role outside of SOA formation (see below) in our land cover change simulations. Gasaerosol partitioning in the sulfate-nitrate-ammonium system is described according to the thermodynamic ISORROPIA II equilibrium model (Fountoukis and Nenes, 2007).

Carbonaceous aerosol sources include primary emissions from fossil fuel, biofuel, and biomass burning (Park et al., 2003) and reversible SOA formation following Pye et al. (2010). Secondary organic aerosol are lumped into five species based on the parent hydrocarbons (terpenes, isoprene, light aromatics, and intermediate volatile organic compounds, semivolatile organic compounds (SVOCs), and oxidized SVOCs). Aerosol yields are parameterized using a volatility basis set (Donahue et al., 2006) for aerosol systems with multiple parent hydrocarbons or aerosol formation pathways, or an Odum 2-product approach (Odum et al., 1996) for systems with one parent hydrocarbon. Emitted biogenic parent hydrocarbons are lumped in the following manner: (1) $\alpha$-pinene $+\beta$-pinene + sabinine + carene; (2) limonene; (3) t- $\beta$-ocimene + myrcene + other monoterpenes; (4) farnesene + caryophyllene + other sesquiterpenes; and (5) isoprene. SOA yields from ozonolysis (at high and low $\mathrm{NO}_{x}$ ) and nitrate radical oxidation are represented in the model for groups (1)-(4), while yields from photooxidation (initiated by $\mathrm{OH}$ ) and nitrate radical oxidation are represented for isoprene. Further gas-aerosol phase coupling occurs for example through $\mathrm{N}_{2} \mathrm{O}_{5}$ uptake (Evans and Jacob, 2005) and $\mathrm{HO}_{2}$ uptake (Mao et al., 2013).
We use anthropogenic emission inventories according to the NEI-2005 inventory for the United States (http://www. epa.gov/ttnchie1/trends/), CAC for Canada (http://www.ec. gc.ca/pdb/cac/), and BRAVO (Kuhns et al., 2005) for Mexico, and scale these to the year 2010 following van Donkelaar et al. (2008). The model also includes biomass burning emissions (GFED3, Mu et al., 2011), lightning $\mathrm{NO}_{x}$ (Murray et al., 2012), and volcanic $\mathrm{SO}_{2}$ emissions (Fisher et al., 2011). Soil $\mathrm{NO}_{x}$ and BVOC emissions are described below.

\subsection{Default land-atmosphere exchange in GEOS-Chem}

Here we briefly describe the main mechanisms in the model by which vegetated land cover impacts atmospheric chemistry.

GEOS-Chem v9-02 includes the Berkeley-Dalhousie Soil $\mathrm{NO}_{x}$ Parameterization (Hudman et al., 2012). In this parameterization, the flux of $\mathrm{NO}_{x}$ from soils is a function of temperature, soil moisture, and emission coefficients which depend on available nitrogen and biome type. Biomes (and basal emission coefficients) are defined according to Steinkamp and Lawrence (2011), with 24 different land cover types. Dry spell length is also included to account for pulsing. A canopy reduction factor is calculated according to leaf area index (LAI), wind speed, and surface resistance, and is designed to simulate the uptake of $\mathrm{NO}_{x}$ by vegetation following soil emission (Wang et al., 1998).

Biogenic VOC emissions from vegetation are calculated using the Model of Emissions of Gases and Aerosols from Nature (MEGAN v2.02: Guenther et al., 2006, with updates from Sakulyanontvittaya et al., 2008). In GEOS-Chem v902, mapped basal BVOC emission factors are provided as an input to the model and are modulated online by activity factors that are a function of temperature, LAI, photosynthetically active radiation (PAR), and average leaf age.

Dry deposition is calculated by the resistance-in-series scheme of Wesely (1989), using a "big-leaf" approximation where the deposition surface is treated as a single uniform surface (or leaf). Dry deposition velocities are calculated as a combination of aerodynamic resistance $\left(R_{\mathrm{a}}\right)$, laminar layer resistance $\left(R_{\mathrm{b}}\right)$, and surface resistance $\left(R_{\mathrm{c}}\right)$. $R_{\mathrm{a}}$ is calculated separately for unstable, moderately stable, and very stable atmospheric conditions, and is a function of roughness heights (which would be a function of land cover type) that are provided by the meteorological input data. $R_{\mathrm{b}}$ depends on meteorological data and the identity of the gas-phase species being deposited. The $R_{\mathrm{c}}$ parameterization depends on the solubility and reactivity of individual chemical compounds and on land type according to Wesely (1989), and is scaled by LAI. Land types are derived by the USGS global land characteristics database (http://edc2.usgs.gov/glcc/globdoc2_0.php), known also as the Olson Land Map. Over 70 land types are represented and mapped to the 11 deposition surface types given by Wesely (1989). Aerosol deposition is also parameterized by the 
resistance-in-series scheme according to Zhang et al. (2001), with deposition to snow and/or ice as presented by Fisher et al. (2011). Gravitational settling of dust and sea salt is described according to Fairlie et al. (2007) and Alexander et al. (2005) respectively.

As described above, the parameterizations of soil $\mathrm{NO}_{x}$ emissions, BVOC emissions, and dry deposition all depend on LAI in some way. By default, GEOS-Chem uses a MODIS-derived monthly LAI product (Myneni et al., 2007) that is mapped to the GEOS-Chem grid (year-specific or a climatology), and linearly interpolated to daily values.

\subsection{Modifications to land-atmosphere exchange in GEOS-Chem}

Here we document the development of a land use module to describe land-atmosphere exchange in GEOS-Chem and to facilitate simulations involving changes in land cover and land use, such as the tree mortality being explored here.

To increase the flexibility in the BVOC emissions, basal emission factors are now mapped at simulation initialization using input land cover data. As a base input, we use presentday (year 2000) land cover from the Community Land Model (CLM) v. 4 (http://www.cgd.ucar.edu/tss/clm/ and Lawrence et al., 2011). Vegetation is divided into 16 plant functional types (PFTs, Table A1 in the Appendix) and their fractional coverage is mapped globally at a native resolution of $0.23^{\circ} \times$ $0.3125^{\circ}$. We incorporate updated emission factors following MEGAN v2.1 (Guenther et al., 2012).

We also eliminate the dependence of the dry deposition velocities on the Olson Land Map. Instead, the same PFTs that drive BVOC emissions are mapped directly to the 11 deposition types from Wesely (1989). We replace the roughness heights provided by the assimilated meteorological product with values that are specific to the land cover or plant functional type (Table A1). Furthermore, rather than basing dry deposition on the dominant land type at a certain native resolution, the complete sub-grid fractional coverage of all PFT/land types are accounted for. In this way, deposition in the model should be less dependent of the horizontal resolution of the simulation or land cover data set. For soil $\mathrm{NO}_{x}$ emissions, we map the same set of PFTs to the 24 biomes of Steinkamp and Lawrence (2011) based on plant type and latitude (Fig. A1).

To achieve consistency between our land type description and the LAI used in the model, we replace the monthly MODIS-derived gridded LAI with the sub-grid PFT-specific monthly LAI from the CLM4 land cover description, also based on MODIS observations as well as additional cropping data (Lawrence et al., 2011).

In this way, BVOC emissions, soil $\mathrm{NO}_{x}$ emissions, dry deposition, and surface roughness are all newly harmonized to the same land cover input and vegetation density. These changes make it possible to alter the specified PFT distribu- tions and/or fractional coverages, and self-consistently investigate the impact on biosphere-atmosphere exchange.

\subsection{Impact of updates and land use harmonization on GEOS-Chem simulation}

Our modifications to GEOS-Chem impact the emissions, deposition, and simulated concentrations compared to the default model, demonstrating the important role of land cover on atmospheric chemistry. GEOS-Chem and other chemical transport models have previously shown a large sensitivity to land cover data sets (Li et al., 2013) and biogenic emission models (Fiore, 2005; Kim et al., 2014; Zare et al., 2012). Globally, we find annual emissions of isoprene decrease by $14 \%$ from 531 to $459 \mathrm{Tg} \mathrm{yr}^{-1}$ with land use harmonization and updated emission factors. The emissions of some monoterpenes decrease (e.g., $\beta$-pinene, limonene, sabinene, and carene by $10 \%$ or less; ocimene by $36 \%$ ), while others increase significantly ( $\alpha$-pinene by $64 \%$, myrcene by $145 \%$ ). Sesquiterpene emissions increase between 20 and $60 \%$ depending on the species. These changes result from the new maps of PFTs, the updated emission factors from MEGAN v2.1 (Guenther et al., 2012), and the new LAI values used. Our modified global emissions are generally consistent with those for MEGAN v2.1 as formulated by Guenther et al. (2012). For example, our $\alpha$-pinene emissions increase from 40 to $66 \mathrm{Tg} \mathrm{yr}^{-1}$, compared to $66 \mathrm{Tg} \mathrm{yr}^{-1}$ estimated by Guenther et al. (2012). Global soil $\mathrm{NO}_{x}$ emissions, which depend on biome mapping from the PFT data set and LAI, decrease by $2 \%$ compared to the default model (from 9.8 to $9.6 \mathrm{Tg} \mathrm{yr}^{-1}$ ).

Figure 1 shows how all of the modifications impact predicted global monthly mean $\mathrm{O}_{3}$ concentrations for $\mathrm{Au}-$ gust 2010. The spatial agreement between the simulations is very high $(r=0.99)$, suggesting that our modifications have not resulted in significant changes to predicted $\mathrm{O}_{3}$. While the changes that we made to the model were not in principle intended to improve the accuracy of the GEOS-Chem $\mathrm{O}_{3}$ simulation (rather the priority was to more easily enable land-cover change experiments), the updated land cover data and the new consistency in the descriptions modestly improve the spatial correlation (from $r=0.54$ inthedefaultmodeltor $=0.56$ in the modified model) between the simulated and gridded monthly mean $\mathrm{O}_{3}$ observed over North America, Europe, and other locations worldwide (Evans and Sofen, 2015) for the whole year. The modifications tend to decrease the high $\mathrm{O}_{3}$ concentrations at midlatitudes of the Northern and Southern hemispheres. In particular, the high summer bias in monthly mean $\mathrm{O}_{3}$ drops by $0.5-0.9 \mathrm{ppb}$ (e.g., from $\mathrm{RMSE}=15.6-14.8$ in August) while making little difference to winter month $\mathrm{O}_{3}$ (RMSE changed by $<0.3 \mathrm{ppb}$ ). 


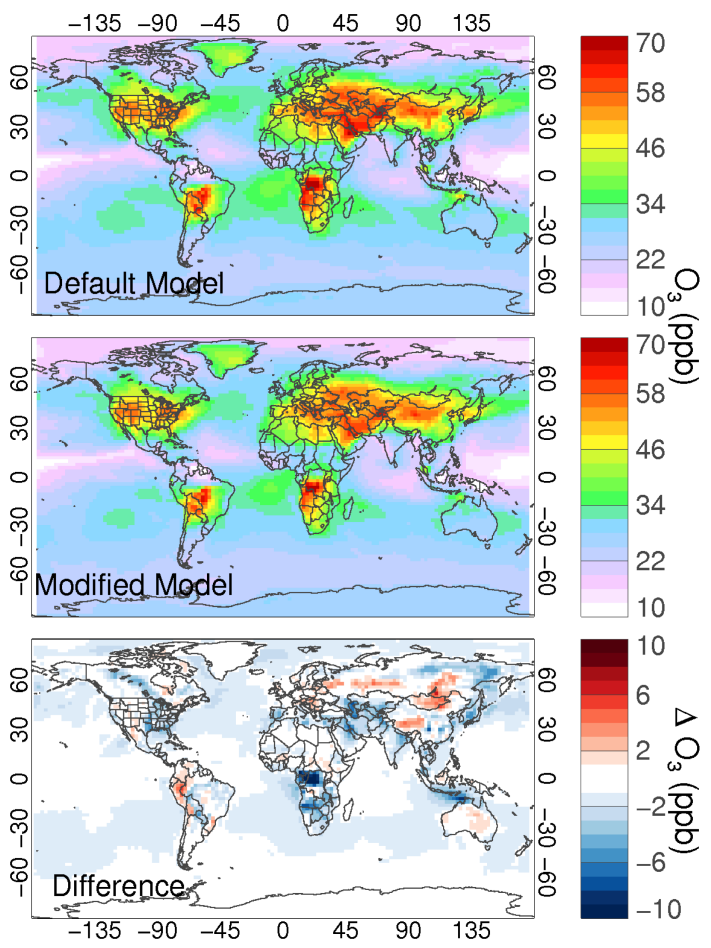

Figure 1. Simulated global surface $\mathrm{O}_{3}$ concentrations for August 2010 in the (top) default, and (middle) modified GEOS-Chem configuration. (Bottom) Difference between the modified and default simulations.

\section{Predicted tree mortality in the United States}

To simulate national-scale tree mortality across the US, we use projected tree mortality rates from the 2012 National Insect and Disease Risk Forest Risk (NIDR) Assessment for 2013-2027, assembled by the Forest Health Technology Enterprise Team of the United States Department of Agriculture Forest Service (Krist et al., 2014). This assessment includes results from 186 individual insect and disease hazard models. We gridded the $240 \mathrm{~m}$ spatially resolved total tree mortality data (http://www.fs.fed.us/foresthealth/technology/ nidrm.shtml) to the native resolution of the new GEOS-Chem land input file $\left(0.23^{\circ} \times 0.31^{\circ}\right)$ and focused on the conterminous United States. We use these data to contrast atmospheric chemistry before vs. after the change in tree cover.

Figure 2 shows the default fractional area covered by the sum of all tree PFT categories, and the resulting loss in tree-covered fractions due to projected mortality after applying the fractional loss from the NIDR. We applied mortality losses predicted by the NIDR to all tree species in a particular input grid box, instead of accounting for losses specific to one plant functional type only. The magnitude and spatial distribution of tree loss is qualitatively consistent with the agent- and species-specific summaries in the NIDR assessment (Krist et al., 2014), since certain PFT categories usually dominate in specific regions or grid boxes. We briefly summarize the major agents driving projected mortality in the NIDR assessment here. In the western US, insects causing evergreen mortality include the mountain, western, and Jeffrey pine beetles, spruce and Douglas fir beetles, the Douglas fir tussock moth, and the Western spruce budworm. In the east, insect-driven evergreen mortality is driven by the Eastern spruce and Jack pine budworm and hemlock woolly adelgid in the north, and the southern pine beetle in the south. Engraver beetles and the balsam woolly adelgid affect evergreens in both the west and east. Deciduous tree mortality is large in the northeast and eastern US, where oak and maple decline is high. Deciduous tree mortality by diseases such as beech bark, oak wilt, and Dutch elm is also large. Aspen and cottonwood declines are significant in the western US and Great Plains. While root diseases, which impact both needleleaf and broadleaf tree categories, represent the largest single agent-level hazard, the impact of all bark beetles together are projected to cause the highest basal area losses (Krist et al., 2014).

\section{Impact of tree mortality on atmospheric chemistry in the US}

We perform four simulations (Table 1) to investigate the role of insect- and disease-driven tree mortality on atmospheric chemistry: (1) a base scenario in which the vegetation is not altered; (2) a scenario where the BVOC emissions respond to the scaled tree cover, but where soil $\mathrm{NO}_{x}$ and dry deposition are calculated using the land cover in the base scenario; (3) a scenario where the BVOC and soil $\mathrm{NO}_{x}$ emissions respond to the scaled tree cover, but where dry deposition is calculated using the land cover in the base scenario; and (4) a full tree mortality scenario where the BVOC emissions, soil $\mathrm{NO}_{x}$ emissions, and dry deposition are all calculated using the scaled tree cover. The combination of these simulations allows us to decouple the effects of changing BVOC and soil $\mathrm{NO}_{x}$ emissions from the effects of changing deposition. We focus our analysis on June-August since this is the seasonal peak in impacts of changes in biogenic emissions on $\mathrm{O}_{3}$ and SOA formation across the United States.

\subsection{Impacts on biogenic emissions and on deposition velocity}

Figure 3 shows the simulated emissions of isoprene, total monoterpenes, and total sesquiterpenes, and the change in emissions due to tree mortality. The impact to total emissions across the US is a $6-7 \%$ decrease for isoprene, monoterpenes, and sesquiterpenes, with much larger impacts locally. Over the continental US, isoprene emissions are projected to decrease by more than $5 \%$ for more than $25 \%$ of the model grid boxes (762 out of a total of 2693). The highest relative impact to isoprene emissions occurs in the Rocky Mountain forests of the northwestern US, where mortality is pro- 

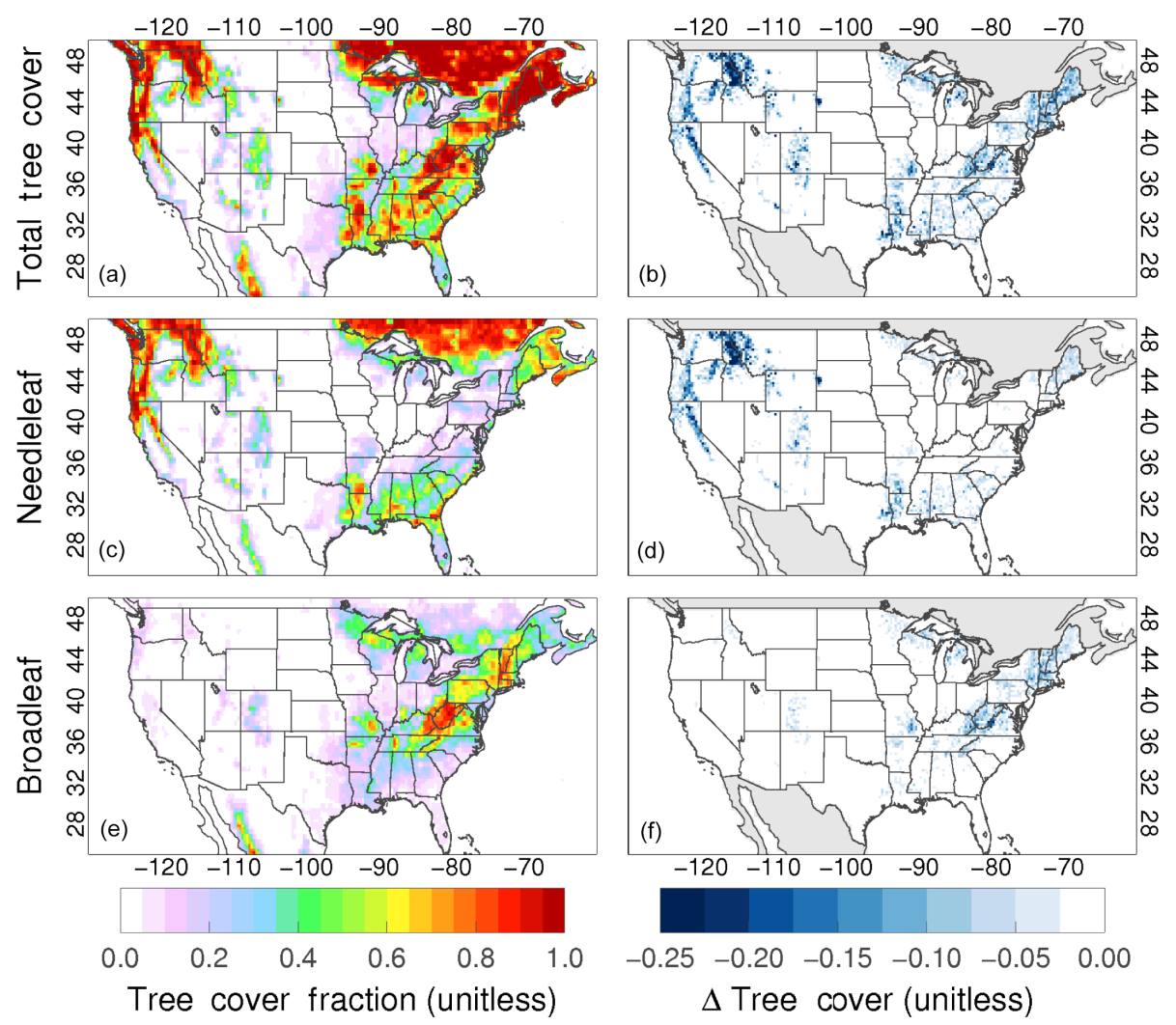

Figure 2. Fraction of grid box covered by trees in present day (left), and the loss in tree cover due to predicted mortality from 2013 to 2027 based on the National Insect and Disease Risk Map (right). (a, b) Total tree cover; (c, d) needleleaf tree cover only; (e, f) broadleaf tree cover only.

Table 1. Descriptions of the individual simulations used here to test the impacts of large-scale tree mortality.

\begin{tabular}{ll}
\hline Simulation & Description \\
\hline 1 & Base land cover simulation (no tree mortality) \\
2 & Tree mortality-driven BVOC emissions (soil $\mathrm{NO}_{x}$ and dry deposition using base land cover) \\
3 & Tree mortality-driven BVOC and soil NOx emissions (dry deposition using base land cover) \\
4 & Tree mortality-driven emissions and dry deposition. \\
\hline
\end{tabular}

jected to be high. For example, the largest relative decrease occurs in Idaho $\left[46.0^{\circ} \mathrm{N}, 115.3^{\circ} \mathrm{W}\right]$ where isoprene emissions decrease by $47 \%\left(1.8 \mu \mathrm{mol} \mathrm{m}^{-2} \mathrm{~h}^{-1}\right)$, compared to the base simulation. These pine-, spruce-, and fir-dominated forests of the northwest are relatively low isoprene emitters compared to the deciduous forests of the eastern US. The reduction in mean $\mathrm{OH}$ reactivity due to tree mortalityinduced isoprene changes in the northwest is $\sim 0.2-0.5 \mathrm{~s}^{-1}$ at most. In the oak-dominated Ozarks of Arkansas and Missouri $\left[\sim 36^{\circ} \mathrm{N}, 92^{\circ} \mathrm{W}\right]$, and the central Appalachian region $\left[\sim 38^{\circ} \mathrm{N}, 81^{\circ} \mathrm{W}\right]$, baseline isoprene emissions are an order of magnitude higher; the corresponding reduction in mean $\mathrm{OH}$ reactivity due to tree mortality-induced isoprene changes exceeds $3 \mathrm{~s}^{-1}$. The highest absolute impact of mortality on isoprene emissions occurs at the border of West Virginia and
Virginia $\left[38.0^{\circ} \mathrm{N}, 80.0^{\circ} \mathrm{W}\right.$, where emissions decrease by $8.6 \mu \mathrm{mol} \mathrm{m}^{-2} \mathrm{~h}^{-1}$ (relative decrease of $26 \%$ ).

Likewise, the highest relative impacts to total monoterpene and total sesquiterpene emissions occur in the Rocky Mountain forests of the western and northwestern US (the largest relative decrease occurs in Colorado $\left[38^{\circ} \mathrm{N}\right.$, $106.7^{\circ} \mathrm{W}$ ] where the monoterpene and sesquiterpene emissions decrease by $48-50 \%$ ). Significant relative impacts are also predicted in the pine forests of the Sierra Nevada $(10-20 \%)$. In terms of absolute magnitude, the difference in monoterpene and sesquiterpene emissions is largest in pine-dominated forests of the southern US. The highest absolute impacts in the country occur in eastern Texas $\left[31.0^{\circ} \mathrm{N}, 94.7^{\circ} \mathrm{W}\right]$ where the monoterpene emissions decrease by $1.4 \mu \mathrm{mol} \mathrm{m}{ }^{-2} \mathrm{~h}^{-1}$ (or $22 \%$ ), and in Arkansas 

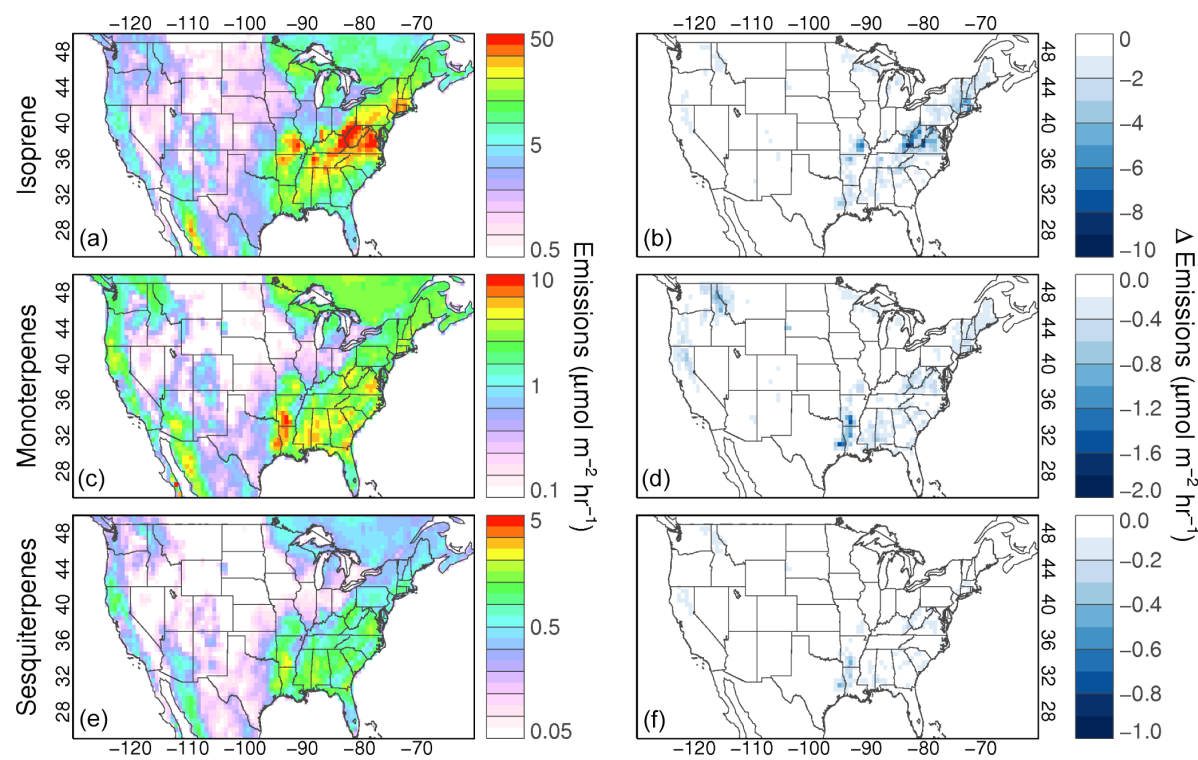

Figure 3. Mean JJA (June-July-August) biogenic VOC emissions in the base scenario (left), and the change in emissions resulting from predicted tree mortality (right). (a, b) Isoprene emissions; $(\mathbf{c}, \mathbf{d})$ total monoterpene emissions; (e, f) total sesquiterpene emissions.
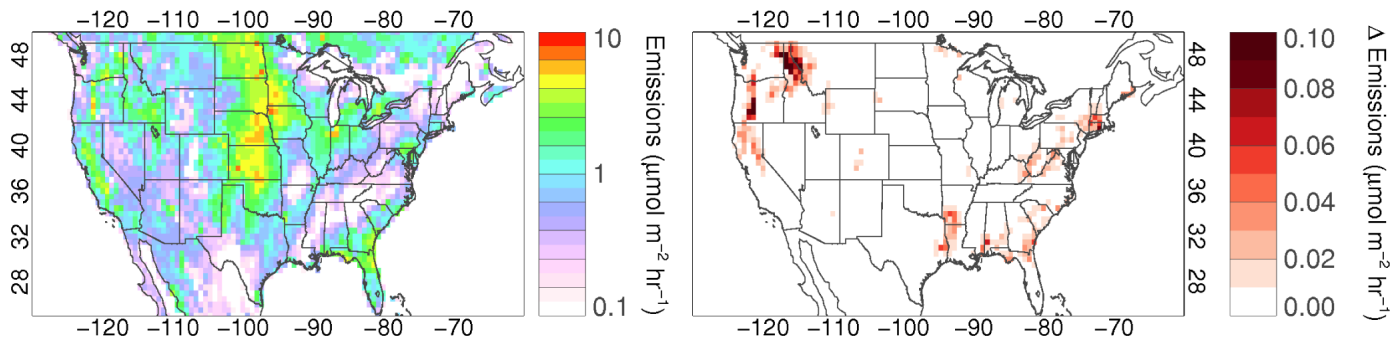

Figure 4. Mean JJA soil $\mathrm{NO}_{x}$ emissions in the base scenario for (left), and the change in emissions resulting from predicted tree mortality (right).

$\left[33.5^{\circ} \mathrm{N}, 92.7^{\circ} \mathrm{W}\right]$ where sesquiterpene emissions decrease by $0.4 \mu \mathrm{mol} \mathrm{m}{ }^{-2} \mathrm{~h}^{-1}$ (or $18 \%$ ) compared to the base simulation.

Figure 4 shows the baseline emissions of $\mathrm{NO}_{x}$ from soils and the simulated change resulting from tree mortality. The highest soil $\mathrm{NO}_{x}$ emissions occur in the central US where crops contribute significantly to the land cover. Soil $\mathrm{NO}_{x}$ emissions are also appreciable in the needleleaf evergreen forests of the northwest and southern US. These forests map to biomes with high $\mathrm{NO}_{x}$ emission factors (about four times greater than for deciduous biomes), resulting in baseline emissions approaching several $\mu \mathrm{mol} \mathrm{m} \mathrm{m}^{-2} \mathrm{~h}^{-1}$. The relative impact of tree mortality on soil $\mathrm{NO}_{x}$ emissions exceeds $10 \%$ in some of these areas (the largest relative difference occurs in western Montana $\left[46^{\circ} \mathrm{N}, 115.3^{\circ} \mathrm{W}\right]$ where soil $\mathrm{NO}_{x}$ emissions increase by $15 \%$ ). In projecting changes to soil $\mathrm{NO}_{x}$ emissions, we allow the canopy reduction factor to respond to changes in LAI, but we assume that the tree mortality does not impact the basal soil $\mathrm{NO}_{x}$ emission factors (nor soil temperature or moisture). The increase in net emission therefore arises from a decrease in canopy reduction factor only, representing the impact of less $\mathrm{NO}_{2}$ uptake by the canopy before export into the lower mixed layer. A better understanding of the canopy reduction factor, and accounting for canopy chemistry, would facilitate a more thorough assessment of these projected increases in soil $\mathrm{NO}_{x}$ emissions.

Figure 5 shows the dry deposition velocity of $\mathrm{O}_{3}$ in the baseline scenario, and the simulated change resulting from tree mortality. In the northeast, where deciduous forests dominate and vegetation is dense, $\mathrm{O}_{3}$ deposition velocities are highest $\left(0.6-0.7 \mathrm{~cm} \mathrm{~s}^{-1}\right)$, whereas the deposition velocity over needleleaf forests is lower $\left(0.3-0.4 \mathrm{~cm} \mathrm{~s}^{-1}\right)$. Lowest deposition velocities occur over the arid and sparsely vegetated regions of the country. Where projected tree mortality is high, $\mathrm{O}_{3}$ deposition velocity decreases by up to $0.08 \mathrm{~cm} \mathrm{~s}^{-1}$ due to reduced stomatal uptake and change in roughness height. The highest absolute impact occurs in the eastern US, along the border of Virginia and West Virginia $\left[38.0^{\circ} \mathrm{N}, 80.0^{\circ} \mathrm{W}\right]$. On a relative basis the impact is largest in the northwest (deposition velocity in northern Idaho $\left[47.5^{\circ} \mathrm{N}, 116.0^{\circ} \mathrm{W}\right]$ decreases 

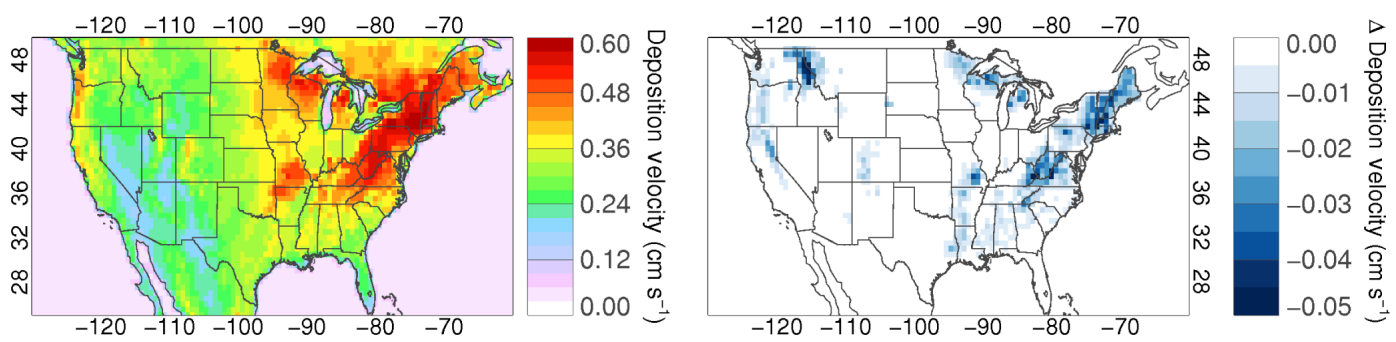

Figure 5. Mean $\mathrm{JJA} \mathrm{O}_{3}$ deposition velocity in the base scenario (left), and the change in deposition velocity resulting from predicted tree mortality (right).

by $16 \%$, or $0.06 \mathrm{~cm} \mathrm{~s}^{-1}$ ). Spatially, the impact on the deposition velocity for other constituents is similar. For example, the deposition velocity of $\mathrm{HNO}_{3}$ (which is largely limited by aerodynamic resistance instead of surface resistance as in the case for $\mathrm{O}_{3}$ ) also decreases in the same regions due to the change in roughness heights in the tree mortality scenario. In this case, decreases in $\mathrm{HNO}_{3}$ deposition velocity exceeding $20 \%$ are predicted in the northwest and eastern US.

\subsection{Impacts on surface ozone concentrations}

Figure 6a shows the June-July-August mean surface $\mathrm{O}_{3}$ concentrations simulated in the base scenario (Simulation 1). The high concentrations in the western US are consistent with previous work and are a consequence of the elevation and the dry climate resulting in a deep boundary layer and slow deposition velocities (Fiore et al., 2002; Wu et al., 2008). High concentrations are also simulated in the eastern US. Figure $6 \mathrm{~b}$ shows the change in simulated $\mathrm{O}_{3}$ concentrations as a result of changes in BVOC and soil $\mathrm{NO}_{x}$ emissions in a tree mortality scenario where deposition is calculated using baseline land cover (Simulation 3 - Simulation 1). Changes in soil $\mathrm{NO}_{x}$ emissions alone increase $\mathrm{O}_{3}$ slightly (Simulation 3 - Simulation 2), but this response is an order of magnitude smaller (or less) than the response to decreased BVOC emissions. The result is a net decrease in $\mathrm{O}_{3}$ on the order of 0.2-0.4 ppb across a large area of the eastern US and in parts of the northwest and California. The largest change occurs in eastern Texas $\left[32.5^{\circ} \mathrm{N}, 94.7^{\circ} \mathrm{W}\right]$ where mean $\mathrm{O}_{3}$ decreases by $0.44 \mathrm{ppb}$. Concentrations increase slightly over the Ozarks of Arkansas and Missouri $\left[\sim 36^{\circ} \mathrm{N}, 92^{\circ} \mathrm{W}\right]$ and the Appalachian region in West Virginia $\left[\sim 38^{\circ} \mathrm{N}, 81^{\circ} \mathrm{W}\right]$.

Figure $6 \mathrm{c}$ shows the simulated change in surface $\mathrm{O}_{3}$ due to tree mortality including the impact of changes to dry deposition (Simulation 4 - Simulation 1). The increase in concentrations due to slower deposition velocities counteracts the decrease in $\mathrm{O}_{3}$ concentrations that result from changes in BVOC emissions alone. In some regions these influences are predicted to be roughly equal so that the net change in $\mathrm{O}_{3}$ is close to zero. However, in many parts of the country including the northeast (e.g., Vermont, New Hampshire, and Maine), and the northwest (northern Idaho and western Montana), the predicted change in deposition is large com- pared to the change from emissions alone, resulting in net increases to $\mathrm{O}_{3}$ approaching 1 ppb or greater. Over the central Appalachian region (most notably West Virginia) and Ozarks the predicted change including dry deposition is also very large compared to the small increase from emissions alone. The highest increase in $\mathrm{O}_{3}$ occurs at the tristate intersection of Kentucky, West Virginia and Virginia $\left[37.5^{\circ} \mathrm{N}, 82.0^{\circ} \mathrm{W}\right.$, where mean $\mathrm{O}_{3}$ is $1.4 \mathrm{ppb}$ higher than in the base simulation. The substantial effect of slower dry deposition underscores the importance of understanding canopy deposition and the potential impact of canopy processes on chemical losses in predictions of land cover change impacts. Given the influence of changes in dry deposition in our simulations, exploring the uncertainties in dry deposition calculations should be a priority for model development.

Since regions where the impact on tree cover is largest are heavily forested and removed from pollution sources, they tend to have relatively low $\mathrm{NO}_{x}$ concentrations. In such situations, $\mathrm{O}_{3}$ production is expected to be $\mathrm{NO}_{x}$-limited so that decreases in VOC emissions weakly impact $\mathrm{O}_{3}$ formation. This is the case over the central Appalachian and Ozarks regions, where $\mathrm{NO}_{x}$ concentrations are below $1 \mathrm{ppb}$ and BVOC emissions decreased by $10-20 \%$, but where $\mathrm{O}_{3}$ is minimally impacted in the scenario with altered emissions only (Fig. 6b). In these forest environments, the change to dry deposition velocity will be the dominant mechanism impacting $\mathrm{O}_{3}$ concentrations, and indeed we find that $\mathrm{O}_{3}$ increases when all mechanisms are considered (Fig. 6c). On the other hand, in high- $\mathrm{NO}_{x}$ (or polluted) regions, $\mathrm{O}_{3}$ production can be expected to be more sensitive to changes in VOC emissions, and since these areas tend to be more developed, deposition plays a smaller role. As a result, in the scenario considering only changes in emissions we find that the predicted impact to $\mathrm{O}_{3}$ concentrations is relatively large in the heavily populated regions along the coast of the mid-Atlantic (Fig. $\left.6 \mathrm{~b}, \sim 40^{\circ} \mathrm{N}, 74^{\circ} \mathrm{W}\right)$.

In general, we find that the ratio of $\mathrm{NO}_{x}$ to VOC concentrations ( $\mathrm{ppb} \mathrm{NO}_{x} / \mathrm{ppb} \mathrm{C}$ ) in a grid box can explain some of the $\mathrm{O}_{3}$ response to changes in tree cover across the US, despite varying degrees of predicted land cover change. Figure 7 shows histograms of the change in surface $\mathrm{O}_{3}$ concentrations for two populations of grid boxes that had changes in 

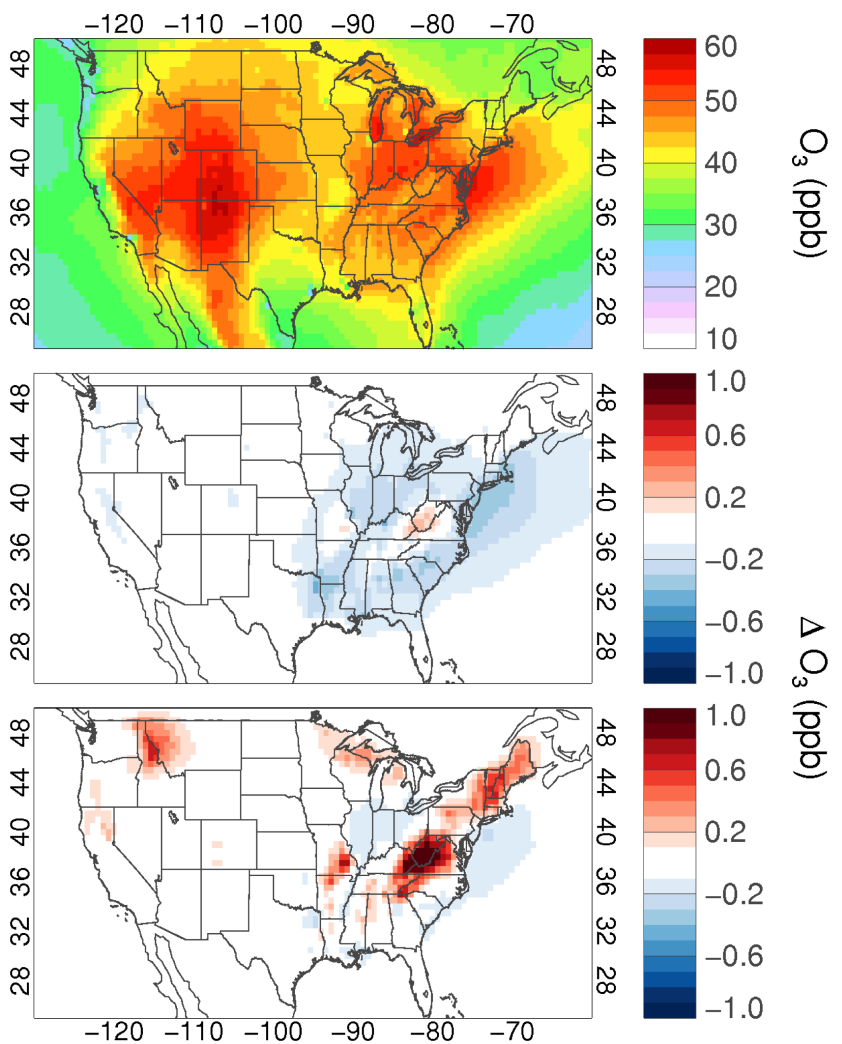

Figure 6. Top: mean JJA surface $\mathrm{O}_{3}$ concentrations in the base simulation (Simulation 1). Middle: the change in $\mathrm{O}_{3}$ concentrations resulting from mortality-driven changes in emissions only (Simulation 3 - Simulation 1). Bottom: the change in $\mathrm{O}_{3}$ concentrations resulting from mortality-driven changes in emissions and deposition velocity together (Simulation 4 - Simulation 1).

isoprene emissions of at least $0.1 \mu \mathrm{mol} \mathrm{m}{ }^{-2} \mathrm{~h}^{-1}(N=1115$ grid boxes from a total of 2693 grid boxes in the continental US). These two distributions $(N=111$ in both) are grid boxes with the lowest $10 \% \mathrm{NO}_{x}$ : VOC concentrations in the base scenario, and grid boxes with the highest $10 \%$ $\mathrm{NO}_{x}$ : VOC concentrations in the base scenario. These distributions are statistically different $(p<0.001$, Wilcoxon ranksum test), and represent the general pattern of impact on "clean" and "polluted" regions respectively. The top panel displays results based on the scenario where only biogenic emissions change (Simulation 3 - Simulation 1). Grid boxes with the highest $\mathrm{NO}_{x}$ to VOC ratios tend towards stronger changes in $\mathrm{O}_{3}$ concentrations than the grid boxes with lowest $\mathrm{NO}_{x}$ to VOC ratios. This suggests more generally that in addition to the extent of land cover change, the impacts of tree mortality on $\mathrm{O}_{3}$ can depend on whether the conditions are $\mathrm{NO}_{x}$-limited (low $\mathrm{NO}_{x}$ : VOC) or VOC-limited (high $\mathrm{NO}_{x}$ : VOC). This $\mathrm{NO}_{x}$-dependence of the regional chemistry impacts resulting from land system changes has also been identified by Wiedinmyer et al. (2006) and Hardacre et al. (2013) for example. The bottom panel displays the re-

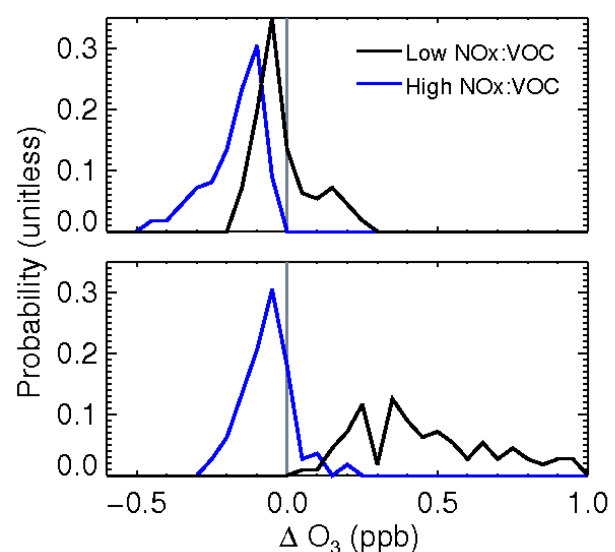

Figure 7. Probability distributions of the change in JJA mean surface $\mathrm{O}_{3}$ concentrations as a result of tree mortality for grid boxes with low $\left(<10\right.$ th percentile) baseline $\mathrm{NO}_{x}$ : VOC emission ratios and high ( $>10$ th percentile) baseline $\mathrm{NO}_{x}$ : VOC emission ratios. Top: results from mortality-driven changes in emissions only (Simulation 3 - Simulation 1). Bottom: results from mortality-driven changes in emissions and deposition combined (Simulation 4 Simulation 1).

sults based on the scenario where changes to biogenic emissions and dry deposition are accounted for (Simulation 4 Simulation 1). Here we find that the change in $\mathrm{O}_{3}$ is more frequently positive (increasing $\mathrm{O}_{3}$ compared to the base scenario) in the low $\mathrm{NO}_{x}$ : VOC grid boxes, since the deposition response tends to be large compared to the impact of emissions. In contrast, while slower deposition counteracts some of the decrease in $\mathrm{O}_{3}$ concentrations in the more polluted grid boxes, the net impact remains largely negative (decreasing $\mathrm{O}_{3}$ compared to the base scenario).

The changes in monthly mean ozone mask even larger impacts on shorter timescales (hours) that may be of importance to air quality standards. The magnitude of the impact on surface $\mathrm{O}_{3}$ in the scenario that considered changes to both emissions and deposition is highest during the day and less significant at night due to the diurnal pattern of chemical $\mathrm{O}_{3}$ production and biogenic emissions, and to the strong dependence of modeled deposition velocities on time of day. As a result, the number of days with $\mathrm{O}_{3}$ above a specific threshold changes in many locations depending on the land cover scenario. We consider for example daily maximum $8 \mathrm{~h}$ averages. The EPA has recently revised the $\mathrm{O}_{3}$ air quality standard to be based on $8 \mathrm{~h}$ averages exceeding a threshold of $70 \mathrm{ppb}$ instead of the previous $75 \mathrm{ppb}$ (http://www3. epa.gov/ttn/naaqs/standards/ozone/s_o3_index.html), so we investigate the number of days during June-July-August in each grid box of the US where the $8 \mathrm{~h}$ average $\mathrm{O}_{3}$ exceeds $70 \mathrm{ppb}$. In the scenario considering only a change in emissions (Simulation 3 - Simulation 1), the number of days exceeding an $8 \mathrm{~h} \mathrm{O}_{3}$ concentration of $70 \mathrm{ppb}$ decreases in $16 \%$ of the grid boxes in the lowest $\mathrm{NO}_{x}$ : VOC 

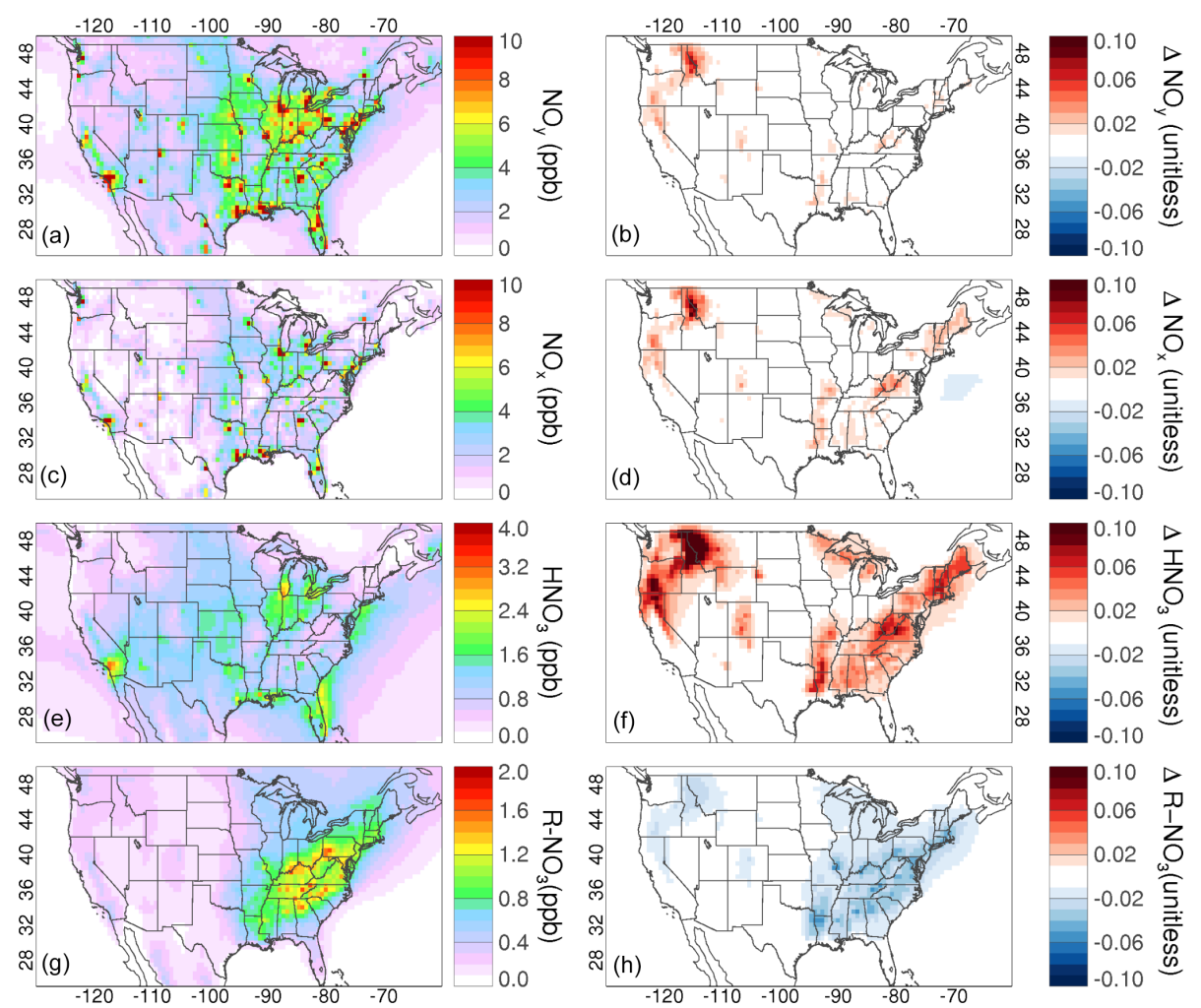

Figure 8. Left: mean JJA mixing ratios of reactive nitrogen oxides in the base scenario (Simulation 1). Right: the relative changes as a result of predicted tree mortality (Simulation 4 - Simulation 1). (a, b) Total $\mathrm{NO}_{y} ;(\mathbf{c}, \mathbf{d}) \mathrm{NO}_{x} ;(\mathbf{e}, \mathbf{f}) \mathrm{HNO}_{3}$; and (g, h) the sum of all alkyl-, peroxy-, and acylperoxy-nitrates.

decile ("clean" regions of the US), and in $45 \%$ of the grid boxes in the highest $\mathrm{NO}_{x}$ : VOC decile ("polluted" regions of the US). Across the US, the number of exceedances decreases by 4 or more days in several regions such as central South Carolina $\left(34.0^{\circ} \mathrm{N}, 81.3^{\circ} \mathrm{W}\right)$, central Kentucky $\left(37.5^{\circ} \mathrm{N},-86.0^{\circ} \mathrm{W}\right)$, central Indiana $\left(38.5^{\circ} \mathrm{N},-90.7^{\circ} \mathrm{W}\right)$, northern Ohio $\left(41.5^{\circ} \mathrm{N}, 83.3^{\circ} \mathrm{W}\right)$, and southwest Michigan $\left(42.0^{\circ} \mathrm{N}, 71.3^{\circ} 20 \mathrm{~W}\right)$. In the scenario considering both the change in biogenic emissions and also the change to deposition rates (Simulation 4 - Simulation 1), many grid boxes experience a net increase in the number of days exceeding an $8 \mathrm{~h} \mathrm{O} 3$ concentration of $70 \mathrm{ppb}$. The increase impacts clean regions disproportionately $\left(30 \%\right.$ of lowest $\mathrm{NO}_{x}$ : VOC grid boxes) compared to polluted regions (5\% of high $\mathrm{NO}_{x}$ : VOC grid boxes). The largest increase is 4 days, which occurs north of Richmond, VA $\left(38.0^{\circ} \mathrm{N}, 77.3^{\circ} \mathrm{W}\right)$. In the same scenario, less than $1 \%$ of the low $\mathrm{NO}_{x}$ : VOC grid boxes experiences a decrease in the number of days exceeding an $8 \mathrm{~h}$ $\mathrm{O}_{3}$ concentration of $70 \mathrm{ppb}$, compared to $26 \%$ of the high $\mathrm{NO}_{x}$ : VOC grid boxes.

\subsection{Impacts on reactive nitrogen oxide compounds}

Figure 8 shows the mixing ratios of reactive nitrogen oxides in the base scenario (Simulation 1), and the simulated changes resulting from tree mortality (Simulation 4 - Simulation 1) on a relative scale (\% change). We plot the results for the sum of all reactive nitrogen oxides $\left(\mathrm{NO}_{y}, \mathrm{Fig} .8 \mathrm{a}\right)$, in addition to the individual contributions from $\mathrm{NO}_{x}$ (Fig. 8c), $\mathrm{HNO}_{3}$ (Fig. 8e) and the sum of all alkyl-, peroxy-, and acylperoxy-nitrates (or "organic nitrates", Fig. 8g). We find that the relative impacts on $\mathrm{NO}_{y}$ and its partitioning as a result of the tree mortality could be locally significant, and are a complex result of all three mechanisms (changes in BVOC emissions, changes in soil $\mathrm{NO}_{x}$, and changes to the deposition velocities), depending on the chemical species. Total $\mathrm{NO}_{y}$ increases by up to $8 \%$ in the northwest (the largest relative increase of $120 \mathrm{ppt}$ is along the Idaho-Montana border $\left.\left[47.5^{\circ} \mathrm{N}, 115.3^{\circ} \mathrm{W}\right]\right)$. The increases here consist of roughly equal increases in $\mathrm{NO}_{x}(79 \mathrm{ppt})$ and $\mathrm{HNO}_{3}(66 \mathrm{ppt})$ mixing ratios with a smaller decrease in organic nitrates (29 ppt). Over the rest of the country, changes in total $\mathrm{NO}_{y}$ are small, in part because the increases in $\mathrm{NO}_{x}$ and $\mathrm{HNO}_{3}$ are counteracted by decreases in organic nitrate species. Significant changes in $\mathrm{NO}_{x}$ abundance and $\mathrm{NO}_{y}$ partitioning could alter the transport and removal of $\mathrm{O}_{3}$ precursors, and alter the peroxy radical chemistry involved in $\mathrm{O}_{3}$ production.

We find that the increases in $\mathrm{NO}_{x}$ are largely a result of elevated soil $\mathrm{NO}_{x}$ emissions (Simulation 3 - Simulation 1). On the other hand, the increases in $\mathrm{HNO}_{3}$, which are up to $18 \%$ 

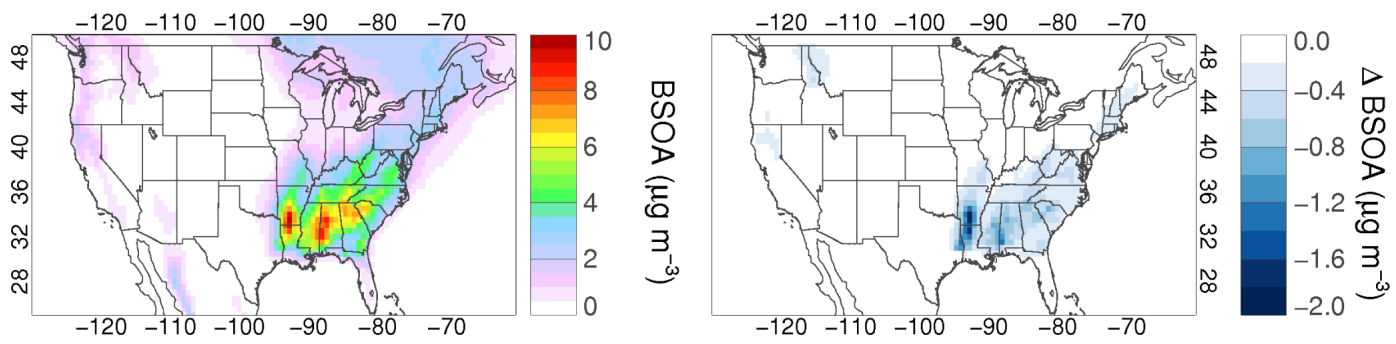

Figure 9. Left: mean JJA biogenic-SOA surface mass concentrations in the base scenario (Simulation 1). Right: the change in biogenic-SOA mass as a result of predicted tree mortality (Simulation 4 - Simulation 1).

on a relative scale, are due to both slower deposition and increasing soil $\mathrm{NO}_{x}$ emissions (Simulation $4-$ Simulation 1). Small increases in $\mathrm{HNO}_{3}$ (locally up to 3-4\%) are also observed in the BVOC emissions only scenario (Simulation $2-$ Simulation 1). Broad decreases in the organic nitrate concentrations (approaching 10\%) are found across large parts of the country. This result is nearly entirely due to the reduction in BVOC emissions alone, with only a small counteracting effect of lower deposition velocities. For example, where the relative impact was largest (a $10 \%$ decrease near Missoula $\left.\operatorname{MT}\left[47^{\circ} \mathrm{N}, 114.7^{\circ} \mathrm{W}\right]\right)$, the decrease from the BVOC emissions alone is $36 \mathrm{ppt}$, while the decrease after accounting for dry deposition and soil $\mathrm{NO}_{x}$ emissions is 29 ppt.

\subsection{Impacts on organic aerosol}

Figure 9a shows the predicted biogenic SOA (BSOA) surface mass concentrations in the base simulation (Simulation 1). The dominant contributors to BSOA over the United States in these simulations are terpenes, consistent with the results of Pye et al. (2010). This results from nitrate radical oxidation included in the SOA mechanism, since terpenes are emitted at night (in addition to during the day) and model aerosol yields from nitrate oxidation are relatively high. The baseline simulation predicts BSOA greater than $3 \mu \mathrm{g} \mathrm{m}^{-3}$ throughout most of the southeast US, approaching $10 \mu \mathrm{g} \mathrm{m}^{-3}$ near the Mississippi-Alabama and Missouri-Arkansas borders. Biogenic SOA contributes $80 \%$ or more of the modeled total OA mass concentration in this region and season. In parts of the northeast and on the west coast, BSOA can also exceed $3 \mu \mathrm{g} \mathrm{m}^{-3}$ and the model predicts the biogenic contribution to total organic aerosol to exceed $50 \%$ there. In the northwest, BSOA approaches $1-2 \mu \mathrm{g} \mathrm{m}^{-3}$.

Figure $9 \mathrm{~b}$ shows the change in BSOA predicted due to tree mortality (Simulation $4-$ Simulation 1 ). In contrast to $\mathrm{O}_{3}$ and $\mathrm{NO}_{y}$ species (where the relative importance of deposition and chemical production could vary), the simulation predicts consistent decreases in BSOA from the tree mortality scenario as a result of decreasing BVOC emissions. The change in atmospheric lifetime as a result of slower dry deposition is negligible (Simulation 4 - Simulation 3). Across the eastern US, BSOA decreases by $5-10 \%$. The relative im- pacts are highest where terpene emissions are significant and projected tree mortality is high due to the dominance of terpenes as precursors to BSOA in these simulations. The impact on BSOA due to tree mortality generally exceeds $10 \%$ where the contributions of terpene emissions represent $50 \%$ or more of total BVOC emissions (in mass carbon). The spatial pattern in $\triangle B S O A$ corresponds most to the relative contribution of the lumped MTPA category of terpenes $(\alpha-$ pinene $+\beta$-pinene + sabinene + carene). In some parts of the southeast the change exceeds $25 \%\left(1-2 \mu \mathrm{g} \mathrm{m}^{-3}\right.$ in terms of absolute mass). The largest absolute impact occurs in southern Arkansas $\left[33.5^{\circ} \mathrm{N}, 92.7^{\circ} \mathrm{W}\right.$, where BSOA decreases by $2.0 \mu \mathrm{g} \mathrm{m}^{-3}$ (or $20 \%$ ). The relative impact is also high in the northwest, where BSOA decreases by $0.5-1 \mu \mathrm{g} \mathrm{m}^{-3}$ (the highest relative difference of $39 \%$ occurs in northern Idaho $\left.\left[46.0^{\circ} \mathrm{N}, 115.3^{\circ} \mathrm{W}\right]\right)$.

Given the dominance of BSOA in much of the US, these changes appreciably impact total OA (and consequently total aerosol mass). Relative impacts to the sum of all organic aerosol are on the order of $20 \%$ or greater in many parts of the south, northwest, and northern California. These simulations suggest that tree mortality and the concomitant change in biogenic emissions has the potential to impact background aerosol levels by up to $2 \mu \mathrm{g} \mathrm{m}^{-3}$ in some regions. This may be of particular relevance to the EPA Regional Haze Program, aimed at improving visibility in national parks and wilderness areas (http://www3.epa.gov/visibility/ program.html).

\section{Discussion}

In this study we develop and apply a land use module for GEOS-Chem to demonstrate that projected tree mortality in the coming decades could impact air quality across the US. We find that the changes in BVOC emissions, soil $\mathrm{NO}_{x}$ emissions, and dry deposition can impact $\mathrm{O}_{3}$ mixing ratios, reactive nitrogen oxide speciation and abundance, and biogenic secondary organic aerosol formation. The magnitude of change in mean $\mathrm{O}_{3}(-0.4$ to $+1.4 \mathrm{ppb}$ depending on the simulation) and SOA (up to $-2.0 \mu \mathrm{g} \mathrm{m}^{-3}$ ) in some grid boxes is similar to regional changes predicted by examples of biofuel cropping or natural succession scenarios (Ashworth et 
al., 2012; Porter et al., 2012; Drewniak et al., 2014), and comparable with the tree mortality effect from past bark beetle infestations simulated in western North America by Berg et al. (2013).

In the case of $\mathrm{O}_{3}$, we find that lower deposition velocities resulting from the change in tree cover could reverse the impact of decreased chemical production. This produces regional variability in the sign of the $\mathrm{O}_{3}$ response depending on which effect dominates locally. Generally, our simulations predict that high levels of $\mathrm{O}_{3}$ could be exacerbated in the low$\mathrm{NO}_{x}$, densely forested areas where mortality is projected to be high. This increase in $\mathrm{O}_{3}$ could have further feedbacks given the documented negative effect of $\mathrm{O}_{3}$ on forest health (Ashmore, 2005; Taylor et al., 1994). Using the number of days when $8 \mathrm{~h} \mathrm{O}_{3}$ exceeds $70 \mathrm{ppb}$, we find that tree mortality generally reduces the number of exceedances for high- $\mathrm{NO}_{x}$ environments.

Our simulations also predict large impacts on organic aerosol. While the exact yields and SOA composition are uncertain (Hallquist et al., 2009) and depend on the SOA model used, the post-disturbance impact is a robust and direct response to a reduction in biogenic emissions (and is not sensitive to changes in deposition). Similar to the reduction in $\mathrm{O}_{3}$ that favors polluted regions, the projected tree mortality could decrease background aerosol levels by up to 1$2 \mu \mathrm{g} \mathrm{m}^{-3}$ locally, inadvertently making progress in other air quality objectives (e.g., long-term visibility at national parks and wilderness areas where mortality is in some cases projected to be high).

These results do not account for changes in anthropogenic emissions that may occur over the same period of time as the changes to vegetation. We therefore performed a subsequent test where the same land cover change was applied, using anthropogenic emissions from 2005 (instead scaling the emissions to 2010 as was performed for Simulations 1-4). Between 2005 and 2010, modeled anthropogenic emissions of $\mathrm{NO}_{x}$ and $\mathrm{SO}_{2}$ over the continental US decreased by 30 and $44 \%$ respectively. Despite this large perturbation in anthropogenic emissions, the predicted impacts due to the land cover change were fundamentally the same. The range of impact on simulated mean $\mathrm{O}_{3}$ over the US due to both emissions and dry deposition combined (Simulation 4 - Simulation 1) went from $\Delta \mathrm{O}_{3}=[-0.24,+1.45] \mathrm{ppb}$ for the 2010 emissions, to $\Delta \mathrm{O}_{3}=[-0.34,+1.35] \mathrm{ppb}$ for the 2005 emissions. Likewise, the maximum impact on SOA changed very little, from $\triangle \mathrm{BSOA}=-2.05 \mu \mathrm{g} \mathrm{m}^{-3}$ in the 2010 simulation, to $\triangle \mathrm{BSOA}=-1.94 \mu \mathrm{g} \mathrm{m}^{-3}$ in the 2005 simulation. Nevertheless, simultaneous changes in both anthropogenic and biogenic emissions increase the uncertainty in the exact magnitude of projected changes in secondary pollutants.

Many opportunities exist for development and incorporating further complexity. For example, these simulations have not accounted for the temporal dynamics of forests undergoing disturbances from insect attack and disease. In the case of insect infestation, VOC emissions can be enhanced during the attack (Amin et al., 2012), and Berg et al. (2013) found that the spatiotemporal patterns in tree mortality can greatly affect the relative impacts of the attack effect vs. the mortality effect on BVOC emissions. Numerous compounds have been observed to be emitted by trees when under stress (Faiola et al., 2015; Joutsensaari et al., 2015) that GEOS-Chem does not yet represent. Not only have we compared simple "pre-" and "post-" disturbance scenarios ignoring attack effects, but we have not considered forest succession. Extensive mortality caused by insects and disease may be compared to forest fires (Hicke et al., 2012), with growth of surviving trees and understory potentially accelerating (Brown et al., 2010). In such cases, BVOC emissions may not necessarily decrease universally, but the composition of those emissions could change over time. Forest recovery after an outbreak may be possible within decades, as has been predicted in the case of bark beetle outbreak in the western US using a forest vegetation simulator (Pfeifer et al., 2011). Successional dynamics could for example be simulated by an individual-based model (e.g., Shuman et al., 2014), and used as inputs at various time points in the chemical transport model. We have also assumed that basal BVOC emission factors for the surviving vegetation are the same as pre-disturbance, but experiments have shown for example that monoterpene basal emission can increase significantly after forest thinning (Schade and Goldstein, 2003), which may or may not be a temporary effect.

Improvements in the parameterization of $\mathrm{O}_{3}$ deposition should also be explored. While we find changes in dry deposition velocity to be an important (and in the majority of cases overriding) factor in our simulation of $\mathrm{O}_{3}$ change, other hypothetical simulations where European crop- and grasslands were converted to poplar plantations for biomass production found that changes from altered dry deposition velocity were an order of magnitude lower than the change in biogenic emissions (Beltman et al., 2013). Dry deposition rates can depend strongly on the choice of model (Hardacre et al., 2015; Park et al., 2014; Wu et al., 2011), making predictions that depend on this uncertain. Improvements can be expected by more accurate representations of land cover (and subsequent changes) (Hardacre et al., 2015), or by including a more process-based model of deposition that depends on soil moisture and vapor deficit (Büker et al., 2012; Pleim et al., 2001). There is also evidence that a significant fraction of the $\mathrm{O}_{3}$ uptake observed over forest canopies is actually an unaccounted for chemical sink (Kurpius and Goldstein, 2003; Rannik et al., 2012; Schade and Goldstein, 2003; Wolfe et al., 2011), but changes in this above-canopy chemistry are not captured in our current set of simulations.

Likewise, canopy chemistry and stand development postdisturbance will affect the predicted impacts on soil $\mathrm{NO}_{x}$ emissions. The impacts of canopy uptake and canopy chemistry resulting from changes in vegetation density and composition could be explored in more detail with future work using a 1-D forest canopy-chemistry model (e.g., Wolfe, 
2011; Ashworth et al., 2015) for the regions where we project large impacts. We have assumed that the basal emissions from the soil after the disturbance will be the same as those prior to the disturbance, but large-scale tree mortality and forest succession have the potential to alter soil biogeochemistry (Gao et al., 2015; Norton et al., 2015; Trahan et al., 2015).

We anticipate the impacts of tree mortality that are simulated here to be conservative. Future climate change is not included in the NIDR assessment, but is expected to increase the risk of mortality from several pests (Krist et al., 2014). Likewise, insect attack could make some tree species more sensitive to climate stresses, resulting in mortality despite what might have been an otherwise non-lethal insect attack (Anderegg et al., 2015). Predictions over the timescale of years and decades will depend on how the insect and/or disease disturbances interact with other abiotic environmental disturbances (e.g., drought, extreme heat), but these interactions are rarely fully coupled (Anderegg et al., 2015). Furthermore, tree mortality from many other factors outside of pests and pathogens are not considered (e.g., competition from invasive exotic plants, drought, or other disturbances). As a result, the actual tree loss in the coming decades, and the concomitant impacts on atmospheric chemistry, may be higher than simulated here. We have also ignored any potential feedback between tree mortality and fire incidence or severity, which is not well understood (Bond et al., 2009). Increases in wildfire (and associated emissions) due to climate change have been predicted to have important consequences for ozone air quality (Yue et al., 2015). Finally, our simulations only explored tree mortality across the United States. No similar large-scale projection of mortality risk exists for Canada, despite insect outbreak already being the dominant cause of tree mortality in boreal forests of eastern Canada (Zhang et al., 2014), and severe (although decreasing) mountain pine beetle infestations in western Canada (Buston and Maclachlan, 2014). Increasing insect outbreaks are also a potential threat to forests elsewhere in the world (Lindner et al., 2010). We note that our simulations neglect any potential human intervention in response to these risks.

\section{Conclusions}

Land use and land cover change is expected to be a major driver of global change that remains difficult to constrain. The change in vegetation that we have explored in these simulations represents one of a myriad of changes that are occurring (and are projected to occur) to the Earth's land surface. We anticipate that these GEOS-Chem model developments will enable investigation of a wide range of land cover and land use change impacts (e.g., vegetation succession, deforestation or afforestation, and crop conversions). Properly representing changes in land cover by including accurate and timely updates to chemical transport models will be an important part of simulating global change. By linking all terrestrial biosphere exchange to plant functional type, our GEOS-Chem developments bring the model a step closer to eventual coupling with dynamic vegetation and/or Earth system models.

Our results add to the literature demonstrating that changes to vegetation can have significant impacts on local chemistry due to changes in biosphere-atmosphere fluxes of reactive trace species, with consequences for controlling regional air quality. Given the general tightening of air quality standards to improve the health of global populations, understanding how changes in land cover will aid or abet these achievements could become increasingly important. 
Table A1. Mapping of CLM-input land types used in the modified version of GEOS-Chem to the Wesely deposition surfaces for deposition, and the associated roughness (Zo) heights for each.

\begin{tabular}{llr}
\hline Land type & Wesely surface & Zo (m) \\
\hline Lake/Ocean & Water & 0.001 \\
Bare Ground & Desert & 0.001 \\
NET Temp & Coniferous forest & 1 \\
NET Boreal & Coniferous forest & 1 \\
NDT Boreal & Coniferous forest & 1 \\
BET Trop & Amazon Rainforest & 1 \\
BET Temp & Deciduous forest & 1 \\
BDT Trop & Deciduous forest & 1 \\
BDT Temp & Deciduous forest & 1 \\
BDT Boreal & Deciduous forest & 1 \\
BES Temp & Shrub/grassland & 0.01 \\
BDS Temp & Shrub/grassland & 0.01 \\
BDS Boreal & Shrub/grassland & 0.01 \\
C3 Arctic GR & Tundra & 0.002 \\
C3 Other GR & Shrub/grassland & 0.01 \\
C4 GR & Shrub/grassland & 0.01 \\
Crop & Agricultural & 0.1 \\
Glacier & Snow/ice & 0.0001 \\
Urban & Urban & 2.5 \\
Wetland & Wetland & 0.05 \\
\hline
\end{tabular}

\section{Appendix A: Land cover classification system}

Table A1 lists the land and plant functional types in the CLM4 land cover description which we use as a base land cover input for our simulations. The table also shows how we have mapped these land cover types to the original $\mathrm{We}$ sely deposition surfaces and to roughness heights for the dry deposition parameterization.

Figure A1 schematically lays out how we have defined biomes in accordance with the nomenclature used for soil $\mathrm{NO}_{x}$ emissions based on the CLM4 land and plant functional type coverage.

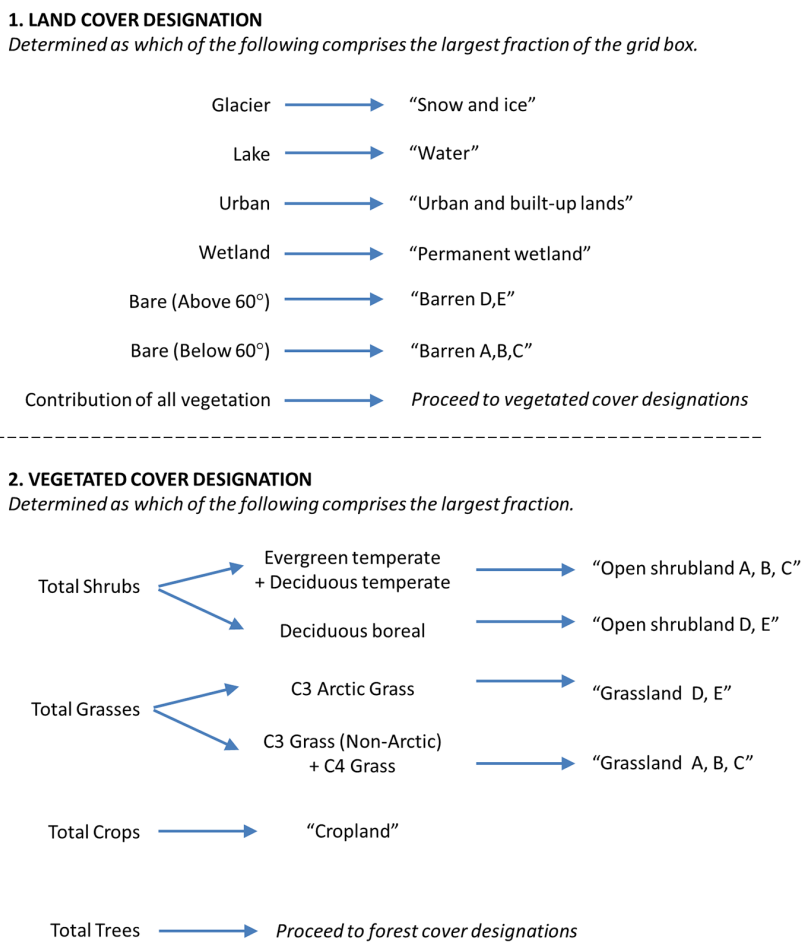

Figure A1. Mapping of native CLM land input classes to soilNOx biomes (according to Steinkamp and Lawrence, 2011) for land cover harmonization in GEOS-Chem. 
Acknowledgements. This work was supported by NSERC and NSF (AGC-1238109). JAG was partially supported by a NSERC CREATE IACPES postdoctoral fellowship and travel grant.

Edited by: A. Perring

\section{References}

Amin, H., Atkins, P. T., Russo, R. S., Brown, A. W., Sive, B., Hallar, A. G., and Huff Hartz, K. E.: Effect of bark beetle infestation on secondary organic aerosol precursor emissions., Environ. Sci. Technol., 46, 5696-5703, doi:10.1021/es204205m, 2012.

Amin, H., Atkins, P. T., Russo, R. S., Brown, A. W., Sive, B., Hallar, A. G., and Huff Hartz, K. E.: Effect of bark beetle infestation on secondary organic aerosol precursor emissions., Environ. Sci. Technol., 46, 5696-5703, doi:10.1021/es204205m, 2012.

Anderegg, W. R. L., Hicke, J. A., Fisher, R. A., Allen, C. D., Aukema, J., Bentz, B., Hood, S., Lichstein, J. W., Macalady, A. K., McDowell, N., Pan, Y., Raffa, K., Sala, A., Shaw, J. D., Stephenson, N. L., Tague, C., and Zeppel, M.: Tree mortality from drought, insects, and their interactions in a changing climate., New Phytol., 208, 674-683, doi:10.1111/nph.13477, 2015.

Arneth, A., Sitch, S., Bondeau, A., Butterbach-Bahl, K., Foster, P., Gedney, N., de Noblet-Ducoudré, N., Prentice, I. C., Sanderson, M., Thonicke, K., Wania, R., and Zaehle, S.: From biota to chemistry and climate: towards a comprehensive description of trace gas exchange between the biosphere and atmosphere, Biogeosciences, 7, 121-149, doi:10.5194/bg-7-121-2010, 2010.

Ashmore, M. R.: Assessing the future global impacts of ozone on vegetation, Plant Cell Environ., 28, 949-964, doi:10.1111/j.1365-3040.2005.01341.x, 2005.

Ashworth, K., Folberth, G., Hewitt, C. N., and Wild, O.: Impacts of near-future cultivation of biofuel feedstocks on atmospheric composition and local air quality, Atmos. Chem. Phys., 12, 919939, doi:10.5194/acp-12-919-2012, 2012.

Ashworth, K., Chung, S. H., Griffin, R. J., Chen, J., Forkel, R., Bryan, A. M., and Steiner, A. L.: FORest Canopy Atmosphere Transfer (FORCAsT) 1.0: a 1-D model of biosphereatmosphere chemical exchange, Geosci. Model Dev., 8, 37653784, doi:10.5194/gmd-8-3765-2015, 2015.

Beltman, J. B., Hendriks, C., Tum, M., and Schaap, M.: The impact of large scale biomass production on ozone air pollution in Europe, Atmos. Environ., 71, 352-363, doi:10.1016/j.atmosenv.2013.02.019, 2013.

Berg, A. R., Heald, C. L., Huff Hartz, K. E., Hallar, A. G., Meddens, A. J. H., Hicke, J. A., Lamarque, J.-F., and Tilmes, S.: The impact of bark beetle infestations on monoterpene emissions and secondary organic aerosol formation in western North America, Atmos. Chem. Phys., 13, 3149-3161, doi:10.5194/acp-13-31492013, 2013.

Bey, I., Jacob, D. J., Yantosca, R. M., Logan, J. A., Field, B. D., Fiore, A. M., Li, Q., Liu, H. Y., Mickley, L. J., and Schultz, M. G.: Global modeling of tropospheric chemistry with assimilated meteorology: model description and evaluation, J. Geophys. Res., 106, 23073, doi:10.1029/2001JD000807, 2001.

Bonan, G. B.: Forests and climate change: forcings, feedbacks, and the climate benefits of forests, Science, 320, 1444-1449, 2008.
Bond, M. L., Lee, D. E., Bradley, C. M., and Hanson, C. T.: Influence of pre-fire tree mortality on fire severity in conifer forests of the San Bernardino Mountains, California, Open For. Sci. J., 2, 41-47, 2009.

Brown, M., Black, T. A., Nesic, Z., Foord, V. N., Spittlehouse, D. L., Fredeen, A. L., Grant, N. J., Burton, P. J., and Trofymow, J. A.: Impact of mountain pine beetle on the net ecosystem production of lodgepole pine stands in British Columbia, Agr. Forest Meteorol., 150, 254-264, doi:10.1016/j.agrformet.2009.11.008, 2010.

Büker, P., Morrissey, T., Briolat, A., Falk, R., Simpson, D., Tuovinen, J.-P., Alonso, R., Barth, S., Baumgarten, M., Grulke, N., Karlsson, P. E., King, J., Lagergren, F., Matyssek, R., Nunn, A., Ogaya, R., Peñuelas, J., Rhea, L., Schaub, M., Uddling, J., Werner, W., and Emberson, L. D.: $\mathrm{DO}_{3} \mathrm{SE}$ modelling of soil moisture to determine ozone flux to forest trees, Atmos. Chem. Phys., 12, 5537-5562, doi:10.5194/acp-12-5537-2012, 2012.

Buston, K. and Maclachlan, L.: 2014 Overview of Forest Health Conditions in Southern British Columbia. Report by the British Columbia Ministry of Forests, Lands, and Natural Resource Operations, Kamloops, BC, 2014.

Chen, J., Avise, J., Guenther, A., Wiedinmyer, C., Salathe, E., Jackson, R. B., and Lamb, B.: Future land use and land cover influences on regional biogenic emissions and air quality in the United States, Atmos. Environ., 43, 5771-5780, doi:10.1016/j.atmosenv.2009.08.015, 2009.

Dale, V. H., Joyce, L. A., McNulty, S., Neilson, R. P., Ayres, M. P., Flannigan, M. D., Hanson, P. J., Irland, L. C., Lugo, A. E., Peterson, C. J., Simberloff, D., Swanson, F. J., Stocks, B. J., and Wotton, M. B.: Climate change and forest disturbances, Bioscience, 51, 723, doi:10.1641/00063568(2001)051[0723:CCAFD]2.0.CO;2, 2001.

Donahue, N., Robinson, A., Stanier, C., and Pandis, S.: Coupled partitioning, dilution, and chemical aging of semivolatile organics, Environ. Sci. Technol., 40, 2635-2643, doi:10.1021/es052297c., 2006.

Drewniak, B. A., Snyder, P. K., Steiner, A. L., Twine, T. E., and Wuebbles, D. J.: Simulated changes in biogenic VOC emissions and ozone formation from habitat expansion of Acer Rubrum (red maple), Environ. Res. Lett., 9, 014006, doi:10.1088/17489326/9/1/014006, 2014.

Evans, M. J. and Jacob, D. J.: Impact of new laboratory studies of $\mathrm{N}_{2} \mathrm{O}_{5}$ hydrolysis on global model budgets of tropospheric nitrogen oxides, ozone, and OH, Geophys. Res. Lett., 32, L09813, doi:10.1029/2005GL022469, 2005.

Evans, M. J. and Sofen, E. D.: Gridded Global Surface Ozone Metrics data (1971-2015) for Atmospheric Chemistry Model Evaluation - version 2.4, Cent. Environ. Data Anal., doi:10.5285/08fbe63d-fa6d-4a7a-b952-5932e3ab0452, 2015.

Faiola, C. L., Jobson, B. T., and VanReken, T. M.: Impacts of simulated herbivory on volatile organic compound emission profiles from coniferous plants, Biogeosciences, 12, 527-547, doi:10.5194/bg-12-527-2015, 2015.

Fairlie, T. D., Jacob, D. J., and Park R. J., The impact of transpacific transport of mineral dust in the United States, Atmos. Environ., 1251-1266, 2007.

Feddema, J. J., Oleson, K. W., Bonan, G. B., Mearns, L. O., Buja, L. E., Meehl, G. A., and Washington, W. M.: The importance of land-cover change in simulating future climates, Science, 310, 1674-1678, doi:10.1126/science.1118160, 2005. 
Fiore, A. M.: Background ozone over the United States in summer: origin, trend, and contribution to pollution episodes, J. Geophys. Res., 107, 4275, doi:10.1029/2001JD000982, 2002.

Fiore, A. M.: Evaluating the contribution of changes in isoprene emissions to surface ozone trends over the eastern United States, J. Geophys. Res., 110, D12303, doi:10.1029/2004JD005485, 2005.

Fisher, J. A., Jacob, D. J., Wang, Q., Bahreini, R., Carouge, C. C., Cubison, M. J., Dibb, J. E., Diehl, T., Jimenez, J. L., Leibensperger, E. M., Lu, Z., Meinders, M. B. J., Pye, H. O. T., Quinn, P. K., Sharma, S., Streets, D. G., van Donkelaar, A., and Yantosca, R. M.: Sources, distribution, and acidity of sulfateammonium aerosol in the Arctic in winter-spring, Atmos. Environ., 45, 7301-7318, doi:10.1016/j.atmosenv.2011.08.030, 2011.

Fountoukis, C. and Nenes, A.: ISORROPIA II: a computationally efficient thermodynamic equilibrium model for $\mathrm{K}^{+}-\mathrm{Ca}^{2+}$ $\mathrm{Mg}^{2+}-\mathrm{NH}^{4+}-\mathrm{Na}^{+}-\mathrm{SO}_{4}^{2-}-\mathrm{NO}_{3}^{-}-\mathrm{Cl}^{-}-\mathrm{H}_{2} \mathrm{O}$ aerosols, Atmos. Chem. Phys., 7, 4639-4659, doi:10.5194/acp-7-4639-2007, 2007.

Ganzeveld, L.: Impact of Amazonian deforestation on atmospheric chemistry, Geophys. Res. Lett., 31, L06105, doi:10.1029/2003GL019205, 2004.

Ganzeveld, L., Bouwman, L., Stehfest, E., van Vuuren, D. P., Eickhout, B., and Lelieveld, J.: Impact of future land use and land cover changes on atmospheric chemistry-climate interactions, J. Geophys. Res., 115, D23301, doi:10.1029/2010JD014041, 2010.

Gao, R., Shi, J., Huang, R., Wang, Z., and Luo, Y.: Effects of pine wilt disease invasion on soil properties and Masson pine forest communities in the Three Gorges reservoir region, China, Ecol. Evol., 5, 1702-1716, doi:10.1002/ece3.1326, 2015.

Guenther, A., Karl, T., Harley, P., Wiedinmyer, C., Palmer, P. I., and Geron, C.: Estimates of global terrestrial isoprene emissions using MEGAN (Model of Emissions of Gases and Aerosols from Nature), Atmos. Chem. Phys., 6, 3181-3210, doi:10.5194/acp-63181-2006, 2006.

Guenther, A. B., Jiang, X., Heald, C. L., Sakulyanontvittaya, T., Duhl, T., Emmons, L. K., and Wang, X.: The Model of Emissions of Gases and Aerosols from Nature version 2.1 (MEGAN2.1): an extended and updated framework for modeling biogenic emissions, Geosci. Model Dev., 5, 1471-1492, doi:10.5194/gmd-51471-2012, 2012.

Hakami, A., Seinfeld, J. H., Chai, T., Tang, Y., Carmichael, G. R., and Sandu, A.: Adjoint Sensitivity Analysis of Ozone Nonattainment over the Continental United States, Environ. Sci. Technol., 40, 3855-3864, doi:10.1021/es052135g, 2006.

Hardacre, C., Wild, O., and Emberson, L.: An evaluation of ozone dry deposition in global scale chemistry climate models, Atmos. Chem. Phys., 15, 6419-6436, doi:10.5194/acp-15-64192015, 2015.

Hallquist, M., Wenger, J. C., Baltensperger, U., Rudich, Y., Simpson, D., Claeys, M., Dommen, J., Donahue, N. M., George, C., Goldstein, A. H., Hamilton, J. F., Herrmann, H., Hoffmann, T., Iinuma, Y., Jang, M., Jenkin, M. E., Jimenez, J. L., Kiendler-Scharr, A., Maenhaut, W., McFiggans, G., Mentel, Th. F., Monod, A., Prévôt, A. S. H., Seinfeld, J. H., Surratt, J. D., Szmigielski, R., and Wildt, J.: The formation, properties and impact of secondary organic aerosol: current and emerging issues, Atmos. Chem. Phys., 9, 5155-5236, doi:10.5194/acp-9-51552009, 2009.
Hardacre, C. J., Palmer, P. I., Baumanns, K., Rounsevell, M., and Murray-Rust, D.: Probabilistic estimation of future emissions of isoprene and surface oxidant chemistry associated with land-use change in response to growing food needs, Atmos. Chem. Phys., 13, 5451-5472, doi:10.5194/acp-13-5451-2013, 2013.

Heald, C. L. and Spracklen, D. V: Land use change impacts on air quality and climate, Chem. Rev., 115, 4476-4496, doi:10.1021/cr500446g, 2015.

Heald, C. L., Henze, D. K., Horowitz, L. W., Feddema, J., Lamarque, J.-F., Guenther, A., Hess, P. G., Vitt, F., Seinfeld, J. H., Goldstein, A. H., and Fung, I.: Predicted change in global secondary organic aerosol concentrations in response to future climate, emissions, and land use change, J. Geophys. Res.-Atmos., 113, D05211, doi:10.1029/2007JD009092, 2008.

Hicke, J. A., Allen, C. D., Desai, A. R., Dietze, M. C., Hall, R. J., Ted Hogg, E. H., Kashian, D. M., Moore, D., Raffa, K. F., Sturrock, R. N., and Vogelmann, J.: Effects of biotic disturbances on forest carbon cycling in the United States and Canada, Glob. Change Biol., 18, 7-34, doi:10.1111/j.1365-2486.2011.02543.x, 2012.

Horowitz, L. W., Walters, S., Mauzerall, D. L., Emmons, L. K., Rasch, P. J., Grainier, C., Tie, X., Lamarque, J. -F., Schultz, M. G., Tyndall, G. S., Orlando, J. J. and Brasseur, G. P.: A global simulation of tropospheric ozone and related tracers: Description and evaluation of MOZART, version 2, J. Geophys. Res.-Atmos., 108, 4784, doi:10.1029/2002JD002853, 2003.

Hudman, R. C., Moore, N. E., Mebust, A. K., Martin, R. V., Russell, A. R., Valin, L. C., and Cohen, R. C.: Steps towards a mechanistic model of global soil nitric oxide emissions: implementation and space based-constraints, Atmos. Chem. Phys., 12, 7779-7795, doi:10.5194/acp-12-7779-2012, 2012.

Joutsensaari, J., Yli-Pirilä, P., Korhonen, H., Arola, A., Blande, J. D., Heijari, J., Kivimäenpää, M., Mikkonen, S., Hao, L., Miettinen, P., Lyytikäinen-Saarenmaa, P., Faiola, C. L., Laaksonen, A., and Holopainen, J. K.: Biotic stress accelerates formation of climate-relevant aerosols in boreal forests, Atmos. Chem. Phys., 15, 12139-12157, doi:10.5194/acp-15-12139-2015, 2015.

Kim, H.-K., Woo, J.-H., Park, R. S., Song, C. H., Kim, J.-H., Ban, S.-J., and Park, J.-H.: Impacts of different plant functional types on ambient ozone predictions in the Seoul Metropolitan Areas (SMAs), Korea, Atmos. Chem. Phys., 14, 7461-7484, doi:10.5194/acp-14-7461-2014, 2014.

Krist, F. J. J., Ellenwood, J. R., Woods, M. E., McMahan, A. J., Cowardin, J. P., Ryerson, D. E., Saplo, F. J., Zwelfler, M. O., and Romero, S. A.: National Insect and Disease Forest Risk Assessment 2013-2027, Fort Collins, CO, available at: http://www. fs.fed.us/foresthealth/technology (last access: 23 October 2015), 2014.

Kuhns, H., Knipping, E. M., and Vukovich, J. M.: Development of a United States-Mexico emissions inventory for the Big Bend Regional Aerosol and Visibility Observational (BRAVO) study, J. Air Waste Manage., 55, 677-692, 2005.

Kurpius, M. R. and Goldstein, A. H.: Gas-phase chemistry dominates $\mathrm{O}_{3}$ loss to a forest, implying a source of aerosols and hydroxyl radicals to the atmosphere, Geophys. Res. Lett., 30, 1371, doi:10.1029/2002GL016785, 2003.

Laothawornkitkul, J., Taylor, J. E., Paul, N. D., and Hewitt, C. N.: Biogenic volatile organic compounds in the Earth System, New Phytol., 183, 27-51, 2009. 
Lawrence, D. M., Oleson, K. W., Flanner, M. G., Thornton, P. E., Swenson, S. C., Lawrence, P. J., Zeng, X., Yang, Z.-L., Levis, S., Sakaguchi, K., Bonan, G. B., and Slater, A. G.: Parameterization improvements and functional and structural advances in Version 4 of the Community Land Model, J. Adv. Model. Earth Syst., 3, M03001, doi:10.1029/2011MS000045, 2011.

Li, M., Wang, Y., and Ju, W.: Effects of a remotely sensed land cover dataset with high spatial resolution on the simulation of secondary air pollutants over china using the nested-grid GEOSchem chemical transport model, Adv. Atmos. Sci., 31, 179-187, doi:10.1007/s00376-013-2290-1, 2013.

Lindner, M., Maroschek, M., Netherer, S., Kremer, A., Barbati, A., Garcia-Gonzalo, J., Seidl, R., Delzon, S., Corona, P., Kolstrom, M., Lexer, M., and Marchetti, M.: Climate change impacts, adaptive capacity, and vulnerability of European forest ecosystems, Forest Ecol. Manag., 259, 698-709, 2010.

MacKenzie, A. R., Langford, B., Pugh, T. A. M., Robinson, N., Misztal, P. K., Heard, D. E., Lee, J. D., Lewis, A. C., Jones, C. E., Hopkins, J. R., Phillips, G., Monks, P. S., Karunaharan, A., Hornsby, K. E., Nicolas-Perea, V., Coe, H., Gabey, A. M., Gallagher, M. W., Whalley, L. K., Edwards, P. M., Evans, M. J., Stone, D., Ingham, T., Commane, R., Furneaux, K. L., McQuaid, J. B., Nemitz, E., Seng, Y., Fowler, D., Pyle, J. A., and Hewitt, C. N.: The atmospheric chemistry of trace gases and particulate matter emitted by different land uses in Borneo, Philos. T. R. Soc. B, 366, 3177-3195, 2011.

Mao, J., Fan, S., Jacob, D. J., and Travis, K. R.: Radical loss in the atmosphere from $\mathrm{Cu}-\mathrm{Fe}$ redox coupling in aerosols, Atmos. Chem. Phys., 13, 509-519, doi:10.5194/acp-13-509-2013, 2013a.

Mao, J., Paulot, F., Jacob, D. J., Cohen, R. C., Crounse, J. D., Wennberg, P. O., Keller, C. A., Hudman, R. C., Barkley, M. P., and Horowitz, L. W.: Ozone and organic nitrates over the eastern United States: Sensitivity to isoprene chemistry. J. Geophys. Res. Atmos., 118, 11256-11268, doi:10.1002/jgrd.50817, 2013.

MEA: Ecosystems and human well-being (Millenium Ecosystem Assessment, World Health Organization), available at: http:// www.who.int/globalchange/ecosystems (last access: 23 October 2015), 2005.

Monson, R. K. and Holland, E. A.: Biospheric trace gas fluxes and their control over tropospheric chemistry, Annu. Rev. Ecol. Syst., 32, 547-576, 2001.

Mellouki, A., Wallington, T. J., and Chen, J.: Atmospheric chemistry of oxygenated volatile organic compounds: Impacts on air quality and climate, Chem. Rev., 115, 3984-4014, doi:10.1021/cr500549n, 2015.

Mu, M., Randerson, J. T., van der Werf, G. R., Giglio, L., Kasibhatla, P., Morton, D., Collatz, G. J., DeFries, R. S., Hyer, E. J., Prins, E. M., Griffith, D. W. T., Wunch, D., Toon, G. C., Sherlock, V., and Wennberg, P. O.: Daily and 3 hourly variability in global fire emissions and consequences for atmospheric model predictions of carbon monoxide, J. Geophys. Res.-Atmos., 116, D24303, doi:10.1029/2011JD016245, 2011.

Murray, L. T., Jacob, D. J., Logan, J. A., Hudman, R. C., and Koshak, W. J.: Optimized regional and interannual variability of lightning in a global chemical transport model constrained by LIS/OTD satellite data, J. Geophys. Res.-Atmos., 117, D20307, doi:10.1029/2012JD017934, 2012.
Myneni, R. B., Yang, W., Nemani, R. R., Huete, A. R., Dickinson, R. E., Knyazikhin, Y., Didan, K., Fu, R., Negrón Juárez, R. I., Saatchi, S. S., Hashimoto, H., Ichii, K., Shabanov, N. V, Tan, B., Ratana, P., Privette, J. L., Morisette, J. T., Vermote, E. F., Roy, D. P., Wolfe, R. E., Friedl, M. A., Running, S. W., Votava, P., El-Saleous, N., Devadiga, S., Su, Y., and Salomonson, V. V: Large seasonal swings in leaf area of Amazon rainforests, P. Natl. Acad. Sci. USA, 104, 4820-4823, doi:10.1073/pnas.0611338104, 2007.

Norton, U., Ewers, B. E., Borkhuu, B., Brown, N. R., and Pendall, E.: Soil nitrogen five years after bark beetle infestation in Lodgepole Pine Forests, SOIL Sci. Soc. Am. J., 79, 282-293, doi:10.2134/csa2015-60-2-5, 2015.

Odum, J. R., Hoffmann, T., Bowman, F., Collins, D., Flagan, R. C., and Seinfeld, J. H.: Gas/particle partitioning and secondary organic aerosol yields, Environ. Sci. Technol., 30, 2580-2585, 1996.

Park, R. J., Jacob, D. J., Chin, M., and Martin, R. V.: Sources of carbonaceous aerosols over the United States and implications for natural visibility, J. Geophys. Res., 108, 4355, doi:10.1029/2002JD003190, 2003.

Park, R. J., Jacob, D. J., Field, B. D., and Yantosca, R. M.: Natural and transboundary pollution influences on sulfate-nitrateammonium aerosols in the United States: implications for policy, J. Geophys. Res., 109, D15204, doi:10.1029/2003JD004473, 2004.

Park, R. J., Hong, S. K., Kwon, H.-A., Kim, S., Guenther, A., Woo, J.-H., and Loughner, C. P.: An evaluation of ozone dry deposition simulations in East Asia, Atmos. Chem. Phys., 14, 7929-7940, doi:10.5194/acp-14-7929-2014, 2014.

Paulot, F., Crounse, J. D., Kjaergaard, H. G., Kroll, J. H., Seinfeld, J. H., and Wennberg, P. O.: Isoprene photooxidation: new insights into the production of acids and organic nitrates, Atmos. Chem. Phys., 9, 1479-1501, doi:10.5194/acp-9-1479-2009, 2009a.

Paulot, F., Crounse, J. D., Kjaergaard, H. G., Kürten, A., St Clair, J. M., Seinfeld, J. H., and Wennberg, P. O.: Unexpected epoxide formation in the gas-phase photooxidation of isoprene, Science, 325, 730-733, doi:10.1126/science.1172910, 2009b.

Pfeifer, E. M., Hicke, J. A., and Meddens, A. J. H.: Observations and modeling of aboveground tree carbon stocks and fluxes following a bark beetle outbreak in the western United States, Glob. Change Biol., 17, 339-350, doi:10.1111/j.13652486.2010.02226.x, 2011.

Pielke, R. A., Pitman, A., Niyogi, D., Mahmood, R., McAlpine, C., Hossain, F., Goldewijk, K. K., Nair, U., Betts, R., Fall, S., Reichstein, M., Kabat, P., and de Noblet, N.: Land use/land cover changes and climate: modeling analysis and observational evidence, Wiley Interdiscip. Rev. Clim. Chang., 2, 828-850, doi:10.1002/wcc.144, 2011.

Pleim, J. E., Xiu, A., Finkelstein, P. L., and Otte, T. L.: A coupled land-surface and dry deposition model and comparison to field measurements of surface heat, moisture, and ozone fluxes, Water Air Soil Pollut., 1, 243-252, doi:10.1023/A:1013123725860, 2001.

Porter, W. C., Barsanti, K. C., Baughman, E. C., and Rosenstiel, T. N.: Considering the air quality impacts of bioenergy crop production: A case study involving arundo donax, Environ. Sci. Tech., 46, 9777-9784, 2012. 
Purves, D. W., Caspersen, J. P., Moorcroft, P. R., Hurtt, G. C., and Pacala, S. W.: Human-induced changes in US biogenic volatile organic compound emissions: evidence from long-term forest inventory data, Glob. Change Biol., 10, 1737-1755, doi:10.1111/j.1365-2486.2004.00844.x, 2004.

Pye, H. O. T., Chan, A. W. H., Barkley, M. P., and Seinfeld, J. H.: Global modeling of organic aerosol: the importance of reactive nitrogen $\left(\mathrm{NO}_{x}\right.$ and $\left.\mathrm{NO}_{3}\right)$, Atmos. Chem. Phys., 10, 1126111276, doi:10.5194/acp-10-11261-2010, 2010.

Rannik, Ü., Altimir, N., Mammarella, I., Bäck, J., Rinne, J., Ruuskanen, T. M., Hari, P., Vesala, T., and Kulmala, M.: Ozone deposition into a boreal forest over a decade of observations: evaluating deposition partitioning and driving variables, Atmos. Chem. Phys., 12, 12165-12182, doi:10.5194/acp-1212165-2012, 2012.

Sakulyanontvittaya, T., Duhl, T., Wiedinmyer, C., Helmig, D., Matsunaga, S., Potosnak, M., Milford, J., and Guenther, A.: Monoterpene and Sesquiterpene Emission Estimates for the United States, Environ. Sci. Technol., 42, 1623-1629, doi:10.1021/es702274e, 2008.

Schade, G. W. and Goldstein, A.: Increase of monoterpene emissions from a pine plantation as a result of mechanical disturbances, Geophys. Res. Lett., 30, 1380, doi:10.1029/2002GL016138, 2003.

Shuman, J. K., Shugart, H. H., and Krankina, O. N.: Testing individual-based models of forest dynamics: issues and an example from the boreal forests of Russia, Ecol. Model., 293, 102110, doi:10.1016/j.ecolmodel.2013.10.028, 2014.

Smith, P., Gregory, P. J., van Vuuren, D., Obersteiner, M., Havlík, P., Rounsevell, M., Woods, J., Stehfest, E., and Bellarby, J.: Competition for land., Philos. T. Roy. Soc. B., 365, 2941-2957, doi:10.1098/rstb.2010.0127, 2010.

Smith, W. B., Vissage, J. S., Darr, D. R., and Sheffield, R. M.: Forest resources of the United States, 1997, St. Paul, M N, available at: http://www.nrs.fs.fed.us/pubs/gtr/gtr_nc219.pdf (last access: 23 October 2015), 2001.

Steinkamp, J. and Lawrence, M. G.: Improvement and evaluation of simulated global biogenic soil NO emissions in an AC-GCM, Atmos. Chem. Phys., 11, 6063-6082, doi:10.5194/acp-11-60632011, 2011.

Taylor, G. E., Johnson, D. W., and Andersen, C. P.: Air pollution and forest ecosystems: a regional to global perspective, Ecol. Appl., 4, 662, doi:10.2307/1941999, 1994.

Trahan, N. A., Dynes, E. L., Pugh, E., Moore, D. J. P., and Monson, R. K.: Changes in soil biogeochemistry following disturbance by girdling and mountain pine beetles in subalpine forests, Oecologia, 177, 981-95, doi:10.1007/s00442-015-3227-4, 2015.

Unger, N.: Human land-use-driven reduction of forest volatiles cools global climate, Nat. Clim. Chang., 4, 907-910, 2014.

van Donkelaar, A., Martin, R. V., Leaitch, W. R., Macdonald, A. M., Walker, T. W., Streets, D. G., Zhang, Q., Dunlea, E. J., Jimenez, J. L., Dibb, J. E., Huey, L. G., Weber, R., and Andreae, M. O.: Analysis of aircraft and satellite measurements from the Intercontinental Chemical Transport Experiment (INTEX-B) to quantify long-range transport of East Asian sulfur to Canada, Atmos. Chem. Phys., 8, 2999-3014, doi:10.5194/acp8-2999-2008, 2008.

Van Vuuren, D. P., Edmonds, J., Kainuma, M., Riahi, K., Thomson, A., Hibbard, K., Hurtt, G. C., Kram, T., Krey, V.,
Lamarque, J.-F., Masui, T., Meinshausen, M., Nakicenovic, N., Smith, S. J., and Rose, S. K.: The representative concentration pathways: an overview, Clim. Change, 109, 5-31, doi:10.1007/s10584-011-0148-z, 2011.

Wang, Y. H., Jacob, D. J., and Logan, J. A.: Global simulation of tropospheric O-3-NOx-hydrocarbon chemistry 1. Model formulation, J. Geophys. Res., 103, 10713-10725, doi:10.1029/98JD00158, 1998.

Wesely, M. L.: Parameterization of surface resistances to gaseous dry deposition in regional-scale numerical models, Atmos. Environ., 23, 1293-1304, doi:10.1016/0004-6981(89)90153-4, 1989.

Wiedinmyer, C., Tie, X., Guenther, A., Neilson, R., and Granier, C.: Future Changes in Biogenic Isoprene Emissions: How Might They Affect Regional and Global Atmospheric Chemistry?, Earth Interact., 10, 1-19, doi:10.1175/EI174.1, 2006.

Wolfe, G. M., Thornton, J. A., McKay, M., and Goldstein, A. H.: Forest-atmosphere exchange of ozone: sensitivity to very reactive biogenic VOC emissions and implications for incanopy photochemistry, Atmos. Chem. Phys., 11, 7875-7891, doi:10.5194/acp-11-7875-2011, 2011.

Wu, S., Mickley, L. J., Jacob, D. J., Rind, D., and Streets, D. G.: Effects of 2000-2050 changes in climate and emissions on global tropospheric ozone and the policy-relevant background surface ozone in the United States, J. Geophys. Res., 113, D18312, doi:10.1029/2007JD009639, 2008.

Wu, S., Mickley, L. J., Kaplan, J. O., and Jacob, D. J.: Impacts of changes in land use and land cover on atmospheric chemistry and air quality over the 21 st century, Atmos. Chem. Phys., 12, $1597-$ 1609, doi:10.5194/acp-12-1597-2012, 2012.

Wu, Z., Wang, X., Chen, F., Turnipseed, A. A., Guenther, A. B., Niyogi, D., Charusombat, U., Xia, B., William Munger, J., and Alapaty, K.: Evaluating the calculated dry deposition velocities of reactive nitrogen oxides and ozone from two community models over a temperate deciduous forest, Atmos. Environ., 45, 2663-2674, 2011.

Yue, X., Mickley, L. J., Logan, J. A., Hudman, R. C., Martin, M. V., and Yantosca, R. M.: Impact of 2050 climate change on North American wildfire: consequences for ozone air quality, Atmos. Chem. Phys., 15, 10033-10055, doi:10.5194/acp-1510033-2015, 2015.

Zare, A., Christensen, J. H., Irannejad, P., and Brandt, J.: Evaluation of two isoprene emission models for use in a longrange air pollution model, Atmos. Chem. Phys., 12, 7399-7412, doi:10.5194/acp-12-7399-2012, 2012.

Zare, A., Christensen, J. H., Gross, A., Irannejad, P., Glasius, M., and Brandt, J.: Quantifying the contributions of natural emissions to ozone and total fine PM concentrations in the Northern Hemisphere, Atmos. Chem. Phys., 14, 2735-2756, doi:10.5194/acp14-2735-2014, 2014.

Zhang, L. M., Gong, S. L., Padro, J., and Barrie, L.: A size-segregated particle dry deposition scheme for an atmospheric aerosol module, Atmos. Environ., 35, 549-560, doi:10.1016/s1352-2310(00)00326-5, 2001

Zhang, X., Lei, Y., Ma, Z., Kneeshaw, D., and Peng, C.: Insect-induced tree mortality of boreal forests in eastern Canada under a changing climate, Ecol. Evol., 4, 2384-2394, doi:10.1002/ece3.988, 2014. 